\title{
Teologi Ibadah dan Spiritualitas Generasi Milenial
}

\author{
Amelia Kimberlyann Rumbiak
}

\begin{abstract}
Abstrak
Diskursus tentang generasi milenial dan persoalan keagamaan telah menjadi sorotan mendunia dalam berbagai sektor hidup. Keberadaan angkatan mereka menjadi komoditi penting saat ini dan ke depannya. Di samping itu, kemajuan teknologi lewat jaringan internet sangat mengikat mereka sehingga generasi milenial adalah sebuah kelompok yang tumbuh dan akrab serta tergantung dengan teknologi gadget yang menTuan-kan media sosial sebagai agama baru mereka. Gereja sebagai konteks pelaksanaan Teologi Ibadah menghadapi kondisi ini. Peringatan dan rekonstruksi solusi dari Marva J. Dawn dan tokoh-tokoh liturgis lainnya turut menunjukkan pentingnya peran ortodoksi, ortopraksis dan ortopati dari Teologi Ibadah untuk menunjukkan tanggung jawab misiologisnya yang bersifat upside-down melalui ibadah kekinian.
\end{abstract}

Kata-kata kunci: Teologi Ibadah, Spiritualitas, Generasi Milenial.

\begin{abstract}
Discourse about millennial generation and religious campaigns has become a worldwide spotlight in various sectors of life. Their existence is the best commodity in human history. In addition, technological advances through the internet are very binding on them so that the millennial generation is a group that grows and is familiar also dependent on gadget technology that masters social media as their new religion. The Church as a Treaty for implementing theology. Warnings and solutions to solutions from Marva J. Dawn and related liturgical figures also support the role of orthodoxy, orthopraxis, and orthopathy from Worship Theology to hold its missiological responsibilities reversed with the help of contemporary worship.
\end{abstract}

Key words: Worship Theology, Spirituality, Millennial Generation.

\section{Pendahuluan}

Tahun 2016 sebuah film box-office berjudul Virtual Revolution yang disutradarai oleh Guy-Roger Duvert dirilis yang merupakan karya cyberpunk independen. Berkisah tentang prediksi dari tahun 2047 ketika lebih dari 75\% populasi, yang dikenal sebagai orang yang terhubung, menghabiskan sebagian besar hidup mereka dalam permainan virtual online (disebut dengan istilah ayat). Beberapa perusahaan dan politisi dengan senang hati menjaga jurang massa tetap berjalan 
melalui game online. Setelah 148 gamer terbunuh dalam serangan virus komputer yang dilakukan oleh kelompok teroris Necromancers, agen bayangan Nash (Mike Dopud) dipekerjakan oleh operator Synterns Corporation Dina (Jane Badler) untuk melacak dan menghilangkan penyerang. ${ }^{79}$

Film tersebut menjadi salah satu contoh konteks kultur gereja di masa mendatang, dunia virtual/dunia maya seolah-olah menjadi "dunia" nyata. Sebuah dunia yang menjadi tantangan bergereja di masa mendatang. Dunia yang semula tersekat oleh perbedaan pilihan politik, budaya dan batas teritorial mengalami perubahan signifikan , saling terhubung dalam gerak dinamis teknologi yang semakin merasuk di dalam segala aspek kehidupan manusia.

Sayangnya apabila kemajuan teknologi sedemikian menyandera manusia yang mendewakan kemampuan pikirnya maka kemungkinan terbesar adalah Allah tersingkir dari kedudukan-Nya di hati manusia. Dalam kondisi semacam ini, Teologi Ibadah turut serta menggumulinya. Teologi Ibadah akan selalu bergeliat bersama perjalanan dan pergumulan teologi, sejarah dan perkembangan situasi tempat gereja berada. Dengan demikian, dapat dikatakan bahwa kontribusi Teologi Ibadah dalam merefleksikan dan memberikan petunjuk bagi pemenuhan tugas gereja di masa kini dan nanti termasuk kepada generasi milenial, sangatlah penting.

Marva J. Dawn dalam tulisannya menyerukan peringatan sekaligus solusi agar gereja mengambil sikap bijak. Sikap bijak yang dimaksud adalah menggumuli konteks kultur tempat gereja berada, kemudian menemukan jalan keluar terbaik, bukan terkontaminasi atau bahkan menumpulkan (dumbing down) tujuan ekklesiologisnya. Untuk menghindari terjadi penumpulan tujuan gereja di tengah-tengah perubahan kulturnya, Dawn mendesak tanggung jawab misiologis dari Teologi Ibadah agar tetap bersifat updown-side. Artinya gereja yang berteologi melalui ibadah perlu berupaya menjalankan misi untuk mengubah dan menyelaraskan nilai-nilai kultur dengan penyataan diri Allah kepada manusia di dalam firman Allah. Dengan satu harapan, manusia dalam kultur yang terjadi dalam masanya akan tetap menanggapi kehadiran

\footnotetext{
${ }^{79}$ Lihat info di https://www.indiegogo.com/projects/virtual-revolution-the-movie. Diakses 12 Februari 2020. Nash adalah hibrida, menghabiskan $1 / 2$ waktu online, $1 / 2$ di dunia nyata. Dihantui kematian cintanya Helena, karena serangan virus. Atas bantuan hacker Morel (Maximilien Poullein), saudara Helena, Nash menghack video keamanan server Interpol. Sementara Synterns menutupi serangan tersebut untuk menghindari keterlibatan Interpol. Nash menyusup ke sel Necromancer dengan mengambil alih avatar online dari salah satu anggotanya.
} 
Allah dengan lebih baik.80

Kini, dalam dekade ke-3 dari abad ke-21,81 kultur dunia tempat Teologi Ibadah sedang bergelut bersama gereja akan didominasi oleh generasi milenial. Generasi yang sangat dekat dan tak terlepas dari teknologi serta arus globalisasi. Kenyataannya di masa mereka, kompilasi ponsel dan media sosial mulai muncul. Tak heran, jika generasi berikutnya akan lebih melek teknologi dibandingkan dengan generasi-generasi sebelumnya.

Apakah kenyataan di atas buruk? Tidak juga. Bagaimanapun juga, teknologi seperti yang ada sekarang merupakan pemberian Allah untuk kemajuan hidup manusia dan dapat berguna sebagai sarana penunjang pelayanan Kristiani. ${ }^{82}$ Hanya saja muncul persoalan baru, kemajuan tanpa ketidakcakapan manusia mengelola dan menyelaraskannya sebagai mahkluk ciptaan Tuhan, Sang Pemberi Hidup. Nurudin dalam judul bukunya Media Sosial: Agama Baru Masyarakat Milenial mengatakan pengaruh gadget telah "menumbuhkan agama baru dalam kehidupan sehari-hari ... bernama media sosial."83 Di sinilah letak permasalahan tersebut.

Mengabaikannya? Sebuah keniscayaan bagi gereja, termasuk Teologi Ibadah untuk berdiam diri, menolak atau sekedar meremehkan keberadaan kultur yang menempel pada generasi milenial. Oleh karena itu, penulis hendak membahas tentang TEOLOGI IBADAH dan GENERASI MILENIAL. Pembahasannya antara lain mengenal sekilas generasi milenial, spiritualitas generasi milenial. Selanjutnya peran ortodoksi, ortopraksis dan ortopati dari Teologi Ibadah, implikasi dan aplikasi Teologi Ibadah terhadap spiritualitas generasi milenial dengan melihat pada peringatan dan

\footnotetext{
${ }^{80}$ Marva, J. Dawn, Reaching Out without Dumbing Down: The Theology of Worship for the Turn of the
}

Century Culture (Grand Rapids, MI: William B. Eerdmans Publishing Company, 1995),17. Dawn menguraikan 3 kultur yang mengelilingi peribadatan masa kini dan perlu mendapat perhatian yaitu kondisi Inside: Teknologi, Kegagalan kelompok Baby Boomers untuk mempertahankan keyakinannya karena perkembangan teknologi, Postmodern; Outside: pemujaan yang berlebihan terhadap budaya kontemporer; walau demikian, sarannya bahwa Kekristenan haruslah mewujudkan kultur ibadah yang Upside-Down: Ibadah, suatu tindakan surversif, mengubah nilai, kebiasaan dan membentuk karakter yang baik. Hal ini justru akan membawa kebahagiaan sejati.

${ }^{81}$ Dekade Millenium ke-3 dimulai dari 1 Januari 2020 - 31 Desember 2029.

${ }^{82}$ Dalam peringatan $500^{\text {th }}$ anniversary of the Reformation, Minneapolis Institute of Art (MIA) membuat

sebuah pameran tentang the chronicles Luther's life and work mengungkapkan pentingnya teknologi "mesin cetak" bagi reformasi Luther. Lihat pada https://www.npr.org/2016/11/20/502437123/how-technology-helpedmartin-luther-change-christianity (diakses 12 Juni 2020).

\footnotetext{
${ }^{83}$ Nurudin, Media Sosial: Agama Baru Masyarakat Milenial (Malang: Intrans Publishing, 2018), xi.
} 
rekonstruksi solusi dari Marva J. Dawn dan tokoh-tokoh liturgis lainnya mengenai tanggung jawab misiologis gereja yang bersifat upside-down melalui ibadah kekinian.

\section{Mengenal Sekilas Generasi Milenial (Y)}

Generasi milenial/Y adalah sebutan yang dipopulerkan oleh Howe dan Strauss, Lancaster dan Stillman (2002), serta Martin dan Tulgan (2002) untuk kelompok demografi yang terlahir setelah generasi X. ${ }^{84}$ Sesudahnya masih terdapat dua generasi yang lebih muda yaitu generasi Z (kelahiran 2001-2010) dan Alpha (kelahiran 2010 sekarang). Generasi milenial dan kedua generasi setelahnya memiliki persamaan yaitu melek teknologi dan disebut digital citizen, namun juga terdapat perbedaan yang signifikan. ${ }^{85}$

Penetapan tahun kelahiran generasi milenial bervariasi. Elwood Carlson dalam The Lucky Few: Between the Greatest Generation and the Baby Boom menetapkan rentang tahun 1983 - 2001 sebagai tahun kelahiran generasi Milenial/Y. Sementara Generation Theory oleh Karl Mannheim yang menjadi preferensi umum dan penulis dalam artikel ini lebih memilih rasio tahun 1980-2000 sebagai batasan usia generasi milenial. Artinya, pada masa ini (2020) usia mereka berkisar antara 20-40 tahun. ${ }^{86}$

Data Badan Pusat Statistik memperlihatkan bahwa penduduk Indonesia dari demografi milenial akan menjadi pertanda masa bonus demografi dengan jumlah yang signifikan yaitu 33.75\% atau sekitar 63 juta, jumlahnya berimbang antara laki-laki dan perempuan. ${ }^{87}$ Sementara IDN Research Institute, mengelompokkan generasi milenial

\footnotetext{
${ }^{84}$ Pencetusnya pakar sejarah - William Strauss \& Neil Howe, dalam Millennials Rising: The Next Great Generation (buku; tahun 2000). Sebutan lain generasi Milenial; melecho boomers, gadget (=peralatan), atau internet. Tapscott (1998) menyebutnya Digital Generation, Zemke et al (2000) berikan nama Nexters, Oblinger (2005) menyebutnya Generasi Y/NetGen.

${ }^{85}$ Generasi Z merupakan Generasi peralihan dari Generasi Milenial/Y ketika teknologi sedang berkembang pesat, sehingga pola pikirnya cenderung serba instan. Generasi Alpha merupakan kelanjutan dari generasi Z, terlahir pada saat teknologi semakin berkembang pesat. Mereka sudah mengenal dan sudah berpengalaman dengan gawai, ponsel pintar dan kecanggihan teknologi lainnya ketika usia mereka yang masih dini. Lebih jelas lihat Yanuar Surya Putra, Dosen Tetap STIE AMA Salatiga dalam THEORETICAL REVIEW : TEORI PERBEDAAN GENERASI di https://jurnal.stieama.ac.id/index.php/ama/article/viewFile/\%20142/133. (diakses 12 Juni 2020).

${ }^{86}$ Badan Pusat Statistik, Statistik Gender Tematik: Profil Generasi Milenial Indonesia (Jakarta: Kementerian Pemberdayaan Perempuan dan Perlindungan Anak, 2018), 13. Hasil survei yang dilaksanakan oleh BPS, yaitu Survei Sosial Ekonomi Nasional (Susenas) dan Survei Angkatan Kerja Nasional (Sakernas).

${ }^{87}$ Badan Pusat Statistik, Statistik Gender Tematik: Profil Generasi Milenial Indonesia (Jakarta: Kementerian Pemberdayaan Perempuan dan Perlindungan Anak, 2018), 13. Hasil survei yang dilaksanakan oleh BPS, yaitu Survei Sosial Ekonomi Nasional (Susenas) dan Survei Angkatan Kerja Nasional (Sakernas).
} 
Indonesia menjadi dua: Junior Millennial (kelahiran 1991-1998) dan Senior Millennial

(kelahiran 1983-1990) menemukan prosentasi perkiraan jumlah yang lebih spesifik. Temuannya menyebutkan bahwa penduduk Indonesia berusia 20-35 pada tahun 2019 mencapai 24\% atau sekitar 63,4 juta dari penduduk kategori usia produktif (14-64 tahun) yang berjumlah 179,1 juta jiwa (67,6 \%). Jumlah yang cukup signifikan. Merekalah penentu wajah Indonesia di masa depan. ${ }^{88}$ Mereka menjadi sumber daya utama untuk berbagai sektor kehidupan: mulai dari pendidikan, kesehatan, politik, sosial, budaya hingga ketenagakerjaan. Sebuah gelombang generasi yang penting dalam hal jumlah maupun kesanggupan mereka.

Yoris Sebastian dalam Generasi Langgas Millennial Indonesia, mencirikan generasi milenial sebagai manusia yang selalu ingin serba cepat, mudah berpindah pekerjaan dalam waktu/singkat dan dinamis, melek teknologi dan dekat dengan media sosial. ${ }^{89}$ Selain penggunaan teknologi, gemar berinovasi yang bermanfaat, mereka termasuk generasi yang unggul dalam pendidikan, Informatif, kreatif dan produktif karena pola pikir open minded. ${ }^{90}$

Tahun 2016, Ericsson grup pernah membuat prediksi perilaku generasi milenial yang meliputi 4.000 responden yang tersebar di 24 negara, termasuk di Indonesia. Salah satunya yang terbukti sekarang, perilaku Streaming Native, karena mereka menghabiskan sekitar tiga jam sehari di depan layar perangkat mobile. Hal ini menunjukkan fakta ketergantungan generasi milennial menonton secara daring (data jaringan), mengandalkan media sosial untuk mendapatkan informasi sebagai platform pelaporan dan sumber berita utama. ${ }^{91}$

${ }^{88}$ IDN Research Institute, https://www.idntimes.com/diakses 10 Februari 2020.

${ }^{89}$ Sebastian, Yoris. Generasi Langgas Milenial Indonesia (Jakarta: Gagas Media, 2016), 12.

${ }^{90}$ Idem. Secara umum The Anchorage Economic Development Corporation (AEDC), Millennial Workforce Report menyebutkan pilihan pekerjaan mereka lebih bebas, tidak terpaku pada jam kerja konvensional: bukan menjadi pegawai k a n t o r a n tetapi mengandalkan pada IT. Karena itu, di Indonesia muncul berbagai aplikasi dan pelayanan seperti Go-jek, Grab, Uber atau Jojonomic, startup yang membuat Jojo Expense, Jojo Payroll dan JojoTimes. lifestyle, traveling, kuliner, fotografi, dipilih sesukanya.

${ }^{91}$ Kemeninfo Indonesia, https://www.kominfo.go.id/content/detail/8566/mengenal-generasimillennial/0/sorotan_media. (Diakses, 10 Februari 2020). Data Badan Keluarga Berencana Nasional (BKKBN): Indonesia mengalami bonus demografi antara 2020-2030. Pada saat itu jumlah usia angkatan kerja (15-64 tahun) mencapai sekitar $70 \%$, sisanya $30 \%$ penduduk - tidak produktif. Puncaknya semakin ideal begitu antara tahun 2028-2030. Setelah itu, komposisi mulai kembali menjauh dari persentase ideal. Oleh sebab itu, bonus demografi hanya akan terjadi sekali dalam sejarah perjalanan sebuah bangsa. 
Sayangnya, hasil studi Taylor, information search behavior mereka sangat problematik. ${ }^{92}$ Lee menyebutnya sebagai generasi too-much information yang menjadikan bergantung pada ponsel pintar alias kecanduan (adiksi) ponsel pintar. Salah satu tandanya adiksi adalah munculnya kegelisahan bila tidak bersentuhan atau mengecek akun sosial media. Ketergantungan yang besar pada teknologi komunikasi dan informasi mengakibatkan dampak klinis seperti gangguan depresi, gangguan kesehatan mental, dan gangguan kecemasan yang keseluruhannya memerlukan intervensi psychoeducational. Selain itu juga, kedekatan dengan keluarga semakin longgar. ${ }^{93}$

Penelitian lain oleh The Nielsen Global Survey of E-commerce terhadap 30 ribu responden pengguna akses internet dalam kaitannya dengan shopping. Hal ini dipermudah karena kemunculan industri 4.0 yang terhubung secara jaringan yang bersifat global. Sayangnya, kebiasaan ini secara global membahayakan. Symantec Chee Choon Hong, Director Asia Consumer Business Norton yang terlibat dalam riset ini mengatakan bahwa dalam kebiasaan berbelanja via daring tersebut, "Generasi milenial secara mengejutkan menunjukkan kebiasaan keamanan daring yang mengendur."94 Kebiasaan mengendurnya keamanan daring menjadikan penggunaan data daring mereka sebagai data kejahatan cyber (cybercrime) mengintip mereka.

Perkembangan dan kesukaan yang meningkat terhadap daring turut mempengaruhi soal-soal kepercayaan generasi milenial secara memprihatinkan. Di satu sisi terdapat kebangkitan keagamaan, namun di sisi lain terdapat skeptisisme. “Dari sisi beragama, psikologi beragama, kelekatan pada agama dan afiliasi pada institusi agama mereka cenderung longgar, yang mereka pentingkan adalah pada moral dan spiritual. Tidak terlalu terpaku pada agama dalam pengertian organized religion."95

${ }^{92}$ Arthur Taylor, "A study of the information search behaviour of the millennial generation," Information Research, Vol. 17 No. 1,(March 2012).

${ }^{93}$ E. Bun Lee, "Too Much Information: Heavy Smartphone and Facebook Utilization by African American Young Adults,” Journal of Black Studies, Vol. 46, No. 1 (January 2015), h. 44-61.

94 Ibid. Data survei membuktikan bahwa $61 \%$ persen konsumen memilih berbelanja menggunakan ponsel pintar, dan $38 \%$ lainnya memilih tablet atau perangkat mobile lain. Sementara, $58 \%$ konsumen lebih memilih menggunakan komputer.

95 Jeane Marie Tulung, dkk, Generasi Milenial Diskursus Teologi, Pendidikan, Dinamika Psikologis dan Kelekatan pada Agama di Era Banjir Informasi (Depok, Rajawali Pers, 2019), xix. 


\section{Akibatnya, munculnya sosok politik-identitas yang agresif dan konsumerisme simbol}

yang naif daripada kebangkitan spiritualitas yang sehat. Pernyataan berikut

memperjelas maksud kebangkitan spiritual yang menyedihkan secara umum pada masa

kini:

"Kebangkitan spiritual memang ada. Sekurang-kurangnya berupa meriapnya tawaran aneka bentuk meditasi dan terapi spiritual atas masalah-masalah emosional, yang makin menggejala dalam kehidupan urban... ini pula penyebab munculnya begitu banyak 'motivator' akhir-akhir ini. Namun semua itu ditandingi sama kuatnya dengan pengutamaan atas tubuh, tampilan fisik dan pesona memburu kekayaan material. Tegangan ini pula yang menjelaskan alasan pimpinanpimpinan spiritual kini banyak yang terperosok dalam aneka kasus, seperti korupsi, skandal seksual, keserakahan material, perilaku konyol di media dan aneka kemunafikan. Jadi di satu pihak, pemimpin religius makin diharapkan sebagai sandaran, pemecahan persoalan, atau pun penentu kiblat spiritual; di pihak lain, mereka ini sering kali justru merupakan sumber persoalan utama."96

\section{Spiritualitas Generasi Milenial: ${ }^{97}$ Sebuah Persoalan atau Berkat?}

Secara singkat, pengenalan terhadap generasi milenial menunjukkan adanya persoalan dan sekaligus sesuatu yang baik di dalamnya. Berikut ini tabel kesimpulan dari beberapa informasi berkaitan dengan "warna spiritualitas" generasi milenial secara umum seperti telah dipaparkan sebelumnya.

\begin{tabular}{|c|c|c|c|}
\hline \multirow[t]{2}{*}{ Tokoh /Penulis } & \multirow[t]{2}{*}{ Pandangan } & \multicolumn{2}{|c|}{ Kategori } \\
\hline & & Positif & Negatif \\
\hline Badan Pusat Statistik & $\begin{array}{l}33.75 \% \text { atau sekitar } 63 \text { juta didominasi oleh generasi } \\
\text { milenial dan mereka menjadi sumber daya utama } \\
\text { untuk berbagai sektor kehidupan. }\end{array}$ & $\sqrt{ }$ & \\
\hline \multirow{2}{*}{$\begin{array}{c}\text { Yoris Sebastian } \\
\text { dalam bukunya } \\
\text { Generasi Langgas } \\
\text { Millennials Indonesia }\end{array}$} & $\begin{array}{l}\text { Selalu ingin serba cepat, dinamis, melek teknologi } \\
\text { dan dekat dengan media sosial }\end{array}$ & $\sqrt{ }$ & \\
\hline & $\begin{array}{l}\text { Mudah berpindah pekerjaan dalam waktu/singkat } \\
\text { dan bergantung pada gadget }\end{array}$ & & $\sqrt{ }$ \\
\hline \multirow[t]{2}{*}{$\begin{array}{c}\text { The Anchorage } \\
\text { Economic } \\
\text { Development } \\
\text { Corporation (AEDC), } \\
\text { Millennial Workforce } \\
\text { Report }\end{array}$} & $\begin{array}{l}\text { Pencipta lapangan pekerjaan dengan mengandalkan } \\
\text { IT dan tidak menyukai menjadi pegawai dengan jam } \\
\text { kerja masuk- keluar kantor yang ketat dan disiplin. } \\
\text { M unculnya pelayanan seperti Go-jek, Grab, Uber } \\
\text { atau Jojonomic, startup yang membuat Jojo Expense, } \\
\text { Jojo Payroll dan JojoTimes menjadi pertanda } \\
\text { kemampuan generasi millenial. }\end{array}$ & $\sqrt{ }$ & $\sqrt{ }$ \\
\hline & $\begin{array}{l}\text { lifestyle, traveling, kuliner, fotografi dengan pola on } \\
\text { demand - sesuai yang mereka sukai, itu yang mereka }\end{array}$ & $\sqrt{ }$ & $\sqrt{ }$ \\
\hline
\end{tabular}

${ }^{96}$ Bartolomeus Samho, dkk, Agama dan Kesadaran Kontemporer (Yogyakarta: Kanisius, 2019), 28-30. ${ }^{97}$ Spiritualitas berasal dari bahasa Latin spiritus artinya 'roh, jiwa atau semangat.' Dalam bahasa Ibrani ruach dan bahasa Yunani pneuma yang berarti 'angin atau nafas.' Jadi spiritualitas dapat diartikan sebagai 'semangat yang menggerakkan sesuatu.' Spirit juga sering dimaknai sebagai entitas, makhluk atau sesuatu bentuk energi yang hidup dan nyata, meskipun tidak kelihatan di mata biasa dan tidak punya badan fisik seperti manusia, namun spirit itu ada dan hidup (Widi, 2008). Dalam penelitian ini, spiritualitas lebih berbicara holistik yaitu secara umum dan terkait dengan konsep spiritualitas Kristen. 


\begin{tabular}{|c|c|c|}
\hline & pilih. & \\
\hline $\begin{array}{l}\text { Penelitian } \\
\text { Ericson grup } \\
(2016)\end{array}$ & $\begin{array}{l}\text { Ketergantungan pada daring (data jaringan) sebagai } \\
\text { Streaming Native, menghabiskan sekitar tiga jam } \\
\text { sehari di depan layar perangkat mobile. } \\
\text { Mengandalkan media sosial untuk mendapatkan } \\
\text { informasi sebagai platform pelaporan dan sumber } \\
\text { berita utama. }\end{array}$ & $\sqrt{ }$ \\
\hline $\begin{array}{l}\text { Arthur Taylor \& } \\
\text { The Nielsen Global } \\
\text { Survey of E- } \\
\text { commerce \& } \\
\text { Symantec Chee C }\end{array}$ & $\begin{array}{l}\text { information search behavior mereka sangat } \\
\text { problematik - kebanyakan untuk shopping namun } \\
\text { mengendurnya keamanan daring menjadikan } \\
\text { penggunaan data daring mereka sebagai data } \\
\text { cybercrime mengintip mereka. }\end{array}$ & $\sqrt{ }$ \\
\hline E. Bun Lee & $\begin{array}{l}\text { Ketergantungan yang besar pada ICT (information, } \\
\text { communcation and technology) mengakibatkan } \\
\text { dampak klinis seperti gangguan depresi (depresive } \\
\text { disorder), gangguan kesehatan mental (mental } \\
\text { health), dan gangguan kecemasan (anxiety disorder) } \\
\text { yang keseluruhannya memerlukan intervensi } \\
\text { psychoeducational. Selain itu juga, kedekatan dengan } \\
\text { keluarga semakin longgar }\end{array}$ & $\sqrt{ }$ \\
\hline $\begin{array}{l}\text { Jeane Marie Tulung, } \\
\text { dkk \& Bartolomeus } \\
\text { Samho, dkk }\end{array}$ & $\begin{array}{l}\text { Dari sisi beragama, psikologi beragama, kelekatan } \\
\text { pada agama dan afiliasi pada institusi agama mereka } \\
\text { cenderung longgar, yang mereka pentingkan adalah } \\
\text { pada moral dan spiritual. Tidak terlalu terpaku pada } \\
\text { agama dalam pengertian organized religion. Terdapat } \\
\text { kebangkitan keagamaan namun di sisi lain terdapat } \\
\text { skeptisisme juga. }\end{array}$ & $\sqrt{ }$ \\
\hline Nuruddin & $\begin{array}{l}\text { Kedekatan, kelekatan dan pemujaan serta "pen- } \\
\text { dewa-an" pada media sosial karena teknologi } \\
\text { informasi melalui jaringan internet telah membuat } \\
\text { generasi ini menjadikan gadget sebagai sumber } \\
\text { informasinya }\end{array}$ & $\sqrt{ }$ \\
\hline
\end{tabular}

Tabel di atas semakin memperjelas persoalan dalam kultur generasi milenial yang perlu menjadi perhatian teologi Kristen, secara khusus teologi ibadah. Generasi yang sangat dekat dan tak terlepas dari teknologi serta arus globalisasi dan mendatangkan tumbuhnya suatu "dewa atau men-tuhan-kan" media sosial yang sekaligus memperlihatkan warna spiritualitasnya. Di sinilah letaknya persoalan utama dari spiritualitas generasi milenial yang perlu mendapat tanggapan dan upaya holistik dari teologi Kristen secara khusus Teologi Ibadah.

Secara khusus, gambaran spiritualitas generasi milenial Kristen pernah menjadi bagian dari beberapa penelitian. Sekitar tahun 1994, sebuah artikel oleh Bryan Myers menyebutkan sekitar 85\% semua orang Amerika yang menerima Yesus melakukannya dalam rentang usia 4-14 tahun (lebih kenal dengan sebutan jendela 4-14). Sepuluh tahun kemudian (bulan Oktober 2004) secara mengejutkan Barna Grup mempublikasikan hasil riset yang menunjukkan kebenaran penelitian Bryan Myers 
sebelumnya. Hanya saja data tentang 85\% usia 4-14 tahun yang mengikut Kristus justru menurun ke angka 43\% yang mengambil keputusan sebelum usia 14 tahun dan hanya 64\% sebelum usia 18 tahun dalam penelitian Barna. Tujuh tahun kemudian (2011) David Kinnaman dari Barna Grup melontarkan hasil penelitiannya dalam buku You Lost Me. Suatu penelitian yang menggambarkan spiritualitas generasi muda di Amerika. Rupanya secara umum, jemaat baru bertambah 64\% tetapi kemudian mereka kehilangan 70\% anggota jemaat yang saat itu menginjak usia antara 18-30 tahun. ${ }^{98}$ Sebuah angkatan besar dari generasi Milenial hilang dari gereja, menyedihkan.

Berbeda dari penelitian Barna Grup, Bilangan Research Center (BRC) yang diketuai oleh Handi Irawan melakukan penelitian spiritualitas generasi muda Indonesia dan menerbitkan hasil penelitiannya tahun 2018. BRC menggunakan 4 elemen spiritualitas seperti Firman Tuhan (yang dibaca dan didengar dalam gereja), Persekutuan/Komunitas (menemukan teman-teman sejati dalam gereja), kepemimpinan melalui teladan dan diperlengkapi atau didukung untuk bertumbuh (mentor dll) sebagai indikator petunjuk spiritualitas mereka. Penelitian terhadap 4.095 generasi muda (usia 15-25 tahun), tersebar di 42 kota, menunjukkan bahwa terdapat pertumbuhan yang sehat dan baik. ${ }^{99}$

Berdasarkan pengkajian keempat elemen yang menjadi aspek pengukur penelitian tentang spiritualitas generasi muda, BRC menemukan jumlah yang cukup menggembirakan sekitar 73\% dari responden menerima Yesus melalui keluarga mereka. Namun di sisi lain, terjadi ketimpangan karena gereja yang seharusnya berperan sebagai penyedia kebutuhan spiritual generasi penerusnya belum maksimal sehingga sekitar 8\% atau sekitar 399 responden meninggalkan gereja. Ketidakmaksimalan gereja menurut riset BRC terkait erat dengan penyediaan ibadah yang membosankan $(13,9 \%)$ dan gereja tidak menyediakan komunitas $(11,2 \%)$. Temuan hasil penelitian BRC juga memperlihatkan pengaruh media yang cukup besar terhadap spiritualitas generasi muda Indonesia. Sayangnya justru gereja mengacuhkan keterlibatan mereka dalam pelayanan yang sudah menjadi "dunia" mereka. Di samping itu beberapa gereja ternyata tidak menyediakan ataupun jika ada sangat minim

\footnotetext{
${ }^{98}$ Bambang Budijanto dalam Dinamika Spiritualitas Generasi Muda Kristen Indonesia (Jakarta: Bilangan Research Center, 2018), 3-5.

99 Ibid.
} 
pelayanan digital friendly (ramah teknologi) guna menyediakan konten-konten yang Kristiani bagi generasi milenial. ${ }^{100}$ Keadaan ini cukup memprihatinkan karena gerejagereja semestinya mendapatkan sejumlah patner pelayanan dari generasi muda yang memiliki kecakapan digital ministry, suatu bagian segoyianya memperlengkapi pelayanan gereja dewasa ini.

Kedekatan generasi milenial dengan teknologi khususnya media sosial tidaklah semata-mata buruk. Alasannya, sekalipun spiritualitas Kristiani berkaitan dengan iman, namun tidaklah mungkin keberadaannya menolak produk dari iptek yang merupakan pemberian Tuhan. Gaudium et Spes (Kegembiraan dan Harapan), dokumen terpanjang dan paling kompleks dari konstitusi pastoral Konsili Vatikan II tentang Gereja di Dunia Modern menyakini kemajuan teknologi sebagai bagian ilmu pengetahuan yang dianugerahi Tuhan bagi manusia. Lebih lanjut Gaudium et Spes mencantumkan penerimaan Konsili Vatikan II terhadap kemajuan ilmu pengetahuan dan kebudayaan sebagai sarana penunjang guna memahami Injil dengan lebih mendalam serta tugas perwartaan yang sejalan dengan perkembangan jaman. Keduanya perlu berada dalam relasi saling membantu agar Kerajaan Allah datang dalam wujud kesejahteraan umat manusia. ${ }^{101}$

Dengan mengacu pada warisan fisologis Patristik dari pemikiran Agustinus tentang dialektikal iman dan akal manusia, Yahya Afandi dalam artikelnya menyebutkan bahwa dunia virtual dapat menjadi jembatan memahami transendental. Yahya menilai bahwa keberadaan teknologi digital seperti sekarang ini merupakan realitas sosial yang tak terhindarkan dalam kehidupan bergereja saat ini. Dengan demikian semestinya tugas gereja adalah "meng-gereja-kan" teknologi dalam pelayanannya bagi dunia. Realitas bergereja semacam ini merupakan sebuah tantangan sekaligus peluang yang besar. $^{102}$

\footnotetext{
${ }^{100}$ Handi Irawan D, dalam Dinamika Spiritualitas Generasi Muda Kristen Indonesia (Jakarta: Bilangan Research Center, 2018), 79-92.

${ }^{101}$ Konsili Vatikan II menghasilkan 16 dokumen, yang terdiri dari 4 konstitusi, 9 dekrit dan 3 pernyataan (deklarasi). Keempat konstitusi tersebut adalah Konstitusi Sacrosanctum Concilium tentang Liturgi Suci, Konstitusi Dogmatis Lumen Gentium tentang Gereja, Konstitusi Dogmatis Dei Verbum tentang Wahyu Ilahi dan Konstitusi Pastoral Gaudium et Spes tentang Gereja dalam Dunia Modern. Lihat Laurentius Sutadi, "Resepsi Gaudium et Spes oleh Gereja Indonesia di https://e-journal.usd.ac.id/index.php/jt/article/view/431. (Diakses 14 Juni 2020).
}

102 Yahya Afandi, “Gereja dan Pengaruh Teknologi Informasi - Digital Ecclesiology,” Jurnal Fidei, vol.1, No.2, (Desember 2018): 273-280. 
Dengan demikian adalah sebuah keniscayaan bagi gereja dan di dalamnya termasuk Teologi Ibadah untuk berdiam diri, menolak atau sekedar meremehkan kultur yang melekat pada generasi milenial. Teologi Ibadah perlu bergandengan dengan gereja, menjalankan fungsi ekklesiastisnya mengembangkan spiritualitas generasi muda milenial. Jelas, ada persoalan menyertai kebangkitan mereka tetapi sekaligus perlu dilihat sebagai kesempatan atau berkat untuk pelayanan dari pihak gereja melalui ibadah yang berpusat pada Kristus (Kristosentris) dan bukan pada manusia sematamata.

\section{Peran Teologi Ibadah terhadap Spiritualitas Generasi Milenial}

Pembahasan peran Teologi Ibadah akan mengadopsi pemikiran tiga serangkai unsur teologis (theological triad) dalam Kekristenan, yaitu ortodoksi, ortopraksis dan ortopathi guna menghasilkan spiritualitas holistik. Penggunaan theological triad usulan Steven J. Land dari kalangan Wesleyan-Pentakostal bukan tanpa alasan. Land sebagaimana dikutip Woodbrigde menegaskan bahwa spiritualitas sejatinya merupakan integrasi antara dasar kepercayaan yang benar (orthodoxy), mempraktikkan kehidupan Kristus (orthopraxy) dan afeksi keindahan Kristus (orthopathy). ${ }^{103}$

\section{Peran Ortodoksi Teologi Ibadah bagi Spiritualitas Generasi Milenial}

Teologi dan spiritualitas saling terpaut satu dengan lainnya. Teologi Ibadah seperti halnya teologi pada umumnya memberikan pijakan kepada spiritualitas secara konteks historis, filosofis dan kerangka konseptual untuk pengalaman bersama dengan Tuhan. Sementara itu, spiritualitas sendiri lahir dari pengalaman kebenaran yang dipercayai dari apa yang Tuhan nyatakan dan menjadikannya hidup dalam kehidupan sehari-hari. Singkatnya, spiritualitas membutuhkan teologi sebagai dasar pijakannya dan teologi membutuhkan spiritualitas sebagai hasil akhir dari berteologi.

Untuk mendapatkan spiritualitas generasi milenial yang sejati maka Teologi Ibadah perlu menunjukkan peran ortodoksinya. Istilah "ortodoksi” berasal dari dua kata Yunani, yaitu "ortho" berarti benar, tepat, lurus, atau tegak; dan "doxa" yang berarti

${ }^{103}$ N. B.Woodbridge, "Living Theologically-Towards A Theology of Christian Practice in Terms of the Theological Triad of Orthodoxy, Orthopraxy and Orthopathy as Portrayed in Isaiah 6:1-8: A Narrative Approach," HTS Teologiese Studies/Theological Studies 66/2, Art. \#807 [2010]: 3). Bagi Land, ortodoksi dan ortopraksi perlu diintegrasikan dengan ortopati oleh karya integratif Roh Kudus (Archer, "Pentecostal," 309, catatan kaki no. 29). 
kepercayaan, kemuliaan atau ibadah. ${ }^{104}$ Jadi istilah ortodoksi berarti kepercayaan (ajaran), kemuliaan atau ibadah yang benar, tepat, lurus dan tegak. Dengan begitu, peran ortodoksi Teologi Ibadah bagi spiritualitas generasi milenial akan terwujud apabila dalam berteologi terdapat dasar pijakan atau dasar kepercayaan, kemuliaan atau ibadah berdiri kokoh dan tegak pada kebenaran firman Allah yang hakiki.

Umumnya terkait dengan teologi, unsur ortodoksi mengacu kepada keyakinan atau kepercayaan terhadap kredo atau doktrin sebagai kebenaran yang menjadi pijakan atau sandaran. G.K. Chesterton menilai ortodoksi secara historis terkait dengan keyakinan awal yang menjadi pegangan erat para Rasul (Apostles's Creed). Di dalam keyakinan tersebut, mereka melihat dirinya sebagai orang-orang yang terpanggil oleh Yesus sehingga bersedia untuk memegang keyakinan itu sebagai pegangan dan memimpin dalam langkah kehidupan. Oleh karena itu, Chesterton mengganggap teologi Kristen yang datang dari iman para Rasul perlu menjadi pusat dari semua etika dan upaya kehidupan semua orang Kristen. ${ }^{105}$

Dipandang dari perjalanan historis Kekristenan, pernyataan Chesterton memang sangat mendasar. Semua ajaran Kekristenan mengacu pada pengajaran Yesus Kristus kepada para Rasul/murid-murid-Nya. Mereka menjadi saksi dan menuliskannya menjadi pegangan bagi Kekristenan masa kini. Secara sederhana, Paul Steven menyebut ortodoksi sebagai doktrin yang menyandarkan dirinya (orto) kepada Kitab Suci. Sebuah Kitab yang Allah rancang untuk menjadi berkat bagi kehidupan sehari-hari, pada saat yang sama untuk menyembah Tuhan (doxa) sebagai tujuan tertinggi manusia. Tujuan akhirnya menciptakan kesalehan sejati yaitu kemanusiaan sejati seperti yang Tuhan kehendaki. ${ }^{106}$

Dalam menjalankan peran ortodoksinya, Teologi Ibadah memiliki dua tugas ganda. Teologi Ibadah melaksanakan revitalisasi dasar kepercayaan dan menjadi patner perjalanan iman agar sejalan dengan dasar kepercayaan. Dalam menjalankan peran ortodoksi untuk revitalisasi dasar kepercayaan, Teologi Ibadah perlu mengembalikan dan mengarahkan spiritualitas generasi milenial kepada dasar kepercayaan (ajaran),

${ }^{104}$ Lih. R. Paul Stevens, "Living Theologically: Toward A Theology of Christian Practice," Themelios 20/3 (1995): 4; Woodbridge, "Theological Triad," 4; Stone dan Duke, Think Theologically, 9.

${ }^{105}$ G.K.Chesterton, Orthodoxy (New York: Dodd, Mead \& Co., 1908), 5.

${ }^{106}$ R. Paul Stevens, "Living Theologically: Toward a Theology of Christian Practice," Leicester:

Themelios

Journal (May 1995) Issue 20:4. 
kemuliaan atau ibadah yang benar, tepat, lurus dan tegak. Keyakinan yang benar, tepat, lurus dan tegak tersebut berdasar pada kebenaran dalam Kitab Suci untuk mengenal Tuhan pencipta alam semesta, Tuhan yang tidak mungkin tergantikan atau teredus oleh siapapun dan apapun hingga kapanpun. Pengenalan terhadap Tuhan pemberi dan pemelihara kehidupan manusia dan alam semesta dengan kasih sayang sejati dalam bimbingan Roh Kudus dan Kitab Suci.

Persoalan kultur generasi milenial merupakan dampak langsung dari kemajuan teknologi dan mempengaruhi perkembangan teologi Kristen. Sonny E. Zaluchu dalam artikelnya, memperlihatkan keprihatiannya terhadap sisi negatif dari kemajuan teknologi bagi perkembangan teologi di abad ke-21. Keprihatinan tersebut terjadi karena: “... ternyata [teknologi] berbalik menjadikan manusia sebagai objeknya, tersandera oleh hasil pikirannya sendiri melalui sejumlah produk teknologi dan justru mereduksi makna Allah yang transenden." Zaluchu mendeteksi penyebab jauhnya Allah dari hidup manusia diakibatkan oleh penekanan terhadap kemampuan pemikiran (intelektualnya). Tulisnya:

“... kecenderungan manusia untuk semakin berpikir praktis (pragmatisme), berorientasi pada pengetahuan atau akalnya (rasionalisme) dan meringkas berbagai kerumitan, proses tradisional yang rumit dan bertele-tele, dalam sebuah shortcut teknologi. Semua menjadi efektifitas dan efisiensi, termasuk di dalamnya urusan modal dan sumber daya manusia tetapi orientasi manusia berubah karena mengarah pada hal-hal yang bisa dibuktikan, melibatkan pengalaman dan hasil pengamatan yang otentik (empirisme)."107

Kondisi ini sangat memprihatinkan karena pendewaan teknologi, manusia mereduksi Allah. Sesungguhnya amat disayangkan memang karena sikap manusia mereduksi Allah terjadi secara masif, tempat manusia lebih mendewakan kesanggupan yang sebenarnya diperoleh dari Tuhan. Jelaslah kondisi semacam ini cukup memprihatinkan. Di sinilah sebenarnya jantung persoalan utama yang menyebabkan teologi Kristen pada umumnya dan Teologi Ibadah secara khusus perlu memberikan kontribusi penting.

Mereduksi Allah dari hidup manusia merupakan kesalahan dalam sebuah perjalanan iman seseorang. Itulah sebabnya, Teologi Ibadah perlu menjalankan tugas ortodoksinya yang kedua yaitu menjadi patner untuk perjalanan iman yang mendasar kuat dalam kepercayaan kepada Kitab Suci. Ketika membicarakan tentang relasi teologi

${ }^{107}$ Sonny E. Zaluchu, Perkembangan Teologi Kristen di Dekade Pertama Abad 21. https://www.researchgate.net/publication/326694067_Perkembangan_Teologi_Kristen_di_dekade_Pertama_Ab ad 21? enrichId=rgreq-df78f4ac4b7dca38f26d66ad7451ae13-

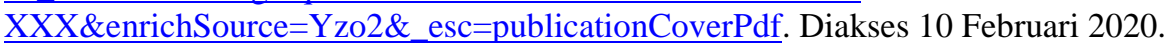


dan spiritual, Barbara E. Bowe memposisikan keduanya sebagai "partner in the dynamic journey of faith."108 Sebagai salah satu dari patner perjalanan iman, Teologi Ibadah harus mendesain sebuah perjalanan spiritualitas yang dinamis berbasis komunitas iman. Sebuah perjalanan iman yang menghadirkan pengalaman personal maupun komunal dengan Tuhan. Tidak heran, Konsili Vatikan II dalam Konstitusi tentang Liturgi Suci mengartikulasikan Teologi Liturgi (baca Teologi Ibadah) harus mampu menjadi patner umat untuk mengekspresikan iman (perpindahan dari iman ke liturgi) dan pada saat yang sama, menginstruksikan atau menginformasikan iman (perpindahan dari liturgi ke iman). Pada tahap selanjutnya memahami efek menjalankan liturgi terhadap iman. 109

Bolt dalam tulisannya menjabarkan empat kategori spektrum pemahaman ortodoksi yang merupakan bukti perjalanan iman yang baik: kesetiaan institusional kepada gereja, ibadah yang benar, integritas pengakuan iman, dan ortodoksi sebagai ortopraksis. ${ }^{110}$ Jika memperhatikan dari keempat spektrum pemahaman ortodoksi Bolt dan membandingkan dengan gambaran spiritualitas generasi milenial secara umum (lihat tabel) jelas adanya tantangan bagi Teologi Ibadah untuk menjalankan kedua peran ortodoksinya yaitu revitalisasi dasar kepercayaan dan menjadi patner perjalanan iman agar sejalan dengan dasar kepercayaan.

\section{Peran Ortopraksis Teologi Ibadah bagi Spiritualitas Generasi Milenial}

Ortopraksis merupakan pelengkap ortodoksi. Secara etimologi, ortopraksis berasal dari dua kata dalam bahsa Yunani ortho (=benar) dan - praxia (yang berarti "praktek" atau "tindakan"). Secara harfiah kata ini memiliki arti “tindakan sejati." 111

${ }^{108}$ Barbara E. Bowe, Biblical Foundations of Spirituality (Maryland: Rowman \& Littlefiled Publishers Inc.,2003), 16.

\footnotetext{
${ }^{109}$ https://www.encyclopedia.com/religion/encyclopedias-almanacs-transcripts-and aps/liturgicaltheology, diakses 20 Mei 2020.

110 John Bolt, "The Problem of Polarization in the Christian Reformed Community," dalam Orthodoxy and Orthopraxis in the Reformed Community Today, ed. John Bolt, vol. 1, Christian Reformed Perspectives [Ontario: Paideia, 1986], 21-25.

${ }^{111}$ Oxford Biblica Studies, “Orthopraxis,” http://www.oxfordbiblicalstudies.com/article/opr/t94/e139 (diakses pada 20 Mei 2020). Dalam kamus Browning mencantumkan teks I Yoh 2:3-6 sebagai dasar biblis bahwa mereka yang mempercayai Kristus haruslah meneladani karakter Kristus bahkan penderitaan-Nya
} 
Menurut Stevens, ortopraksis merupakan adalah "praktik-praktik yang harmonis dengan kerajaan Allah yang membawa nilai dan kebaikan ke dalam dunia."112

Dipandang dari rumpun disiplin ilmu teologi, Teologi Ibadah tergolong ke dalam rumpun Teologi Praktika. Schleiermacher menggunakan analogi sebuah pohon untuk menggambarkan tiga pembagian teologi dan menempatkan Teologi Praktika pada posisi paling atas, ibarat dedaunan dan buah, sebuah organisme yang hidup. Alasannya, Teologi Praktika banyak membicarakan praksis kehidupan komunitas iman. Tidak heran, disebut sebagai the crown of theological studies. ${ }^{113}$ Abineno ketika mengutip pernyataan E. Peningsdorf melihat pertalian erat antara teologi praktika dengan gereja, sebab teologi praktika menjadi hidup gerejawi. Di dalam dan melalui gerejalah, teologi praktika bergerak serta menjalankan tugasnya. ${ }^{114}$ Untuk menuju kepada tugas tersebut, maka Teologi Praktika membutuhkan tindakan holistik dan mencapai sasaran pengayaan pelayanan gereja kepada masyarakat luas. ${ }^{115}$ Inilah peran ortopraksis dari Teologi Ibadah sebagai cabang dari Teologi Praktika.

Dalam tulisannya, Brief Outline on The Study of Theology, Schleiermacher mendaftarkan beberapa aktivitas Teologi Praktika yang menjadi bagian dari pelayanan gereja (pastoral) dan menyebutkan ibadah atau liturgi sebagai salah satu aktivitas yang dimaksud. Aktivitas lainnya antara lain: penggembalaan, khotbah dan pengajaranpengajaran lain (katekisasi), pelayanan sosial, struktur atau hierarki jabatan gereja. ${ }^{116}$

Secara substansial, Teologi Ibadah sangat mumpuni untuk menjadi dasar pijakan spiritualitas generasi milenial. Sebagai salah satu cabang teologi Kristen, Teologi Ibadah bersifat sistematis dan pastoral. Secara sistematis, Teologi Ibadah mengeksplorasi pertanyaan-pertanyaan teologis mendasar dan pelaksanaan kepercayaan atau iman dengan caranya sendiri ( lex orandi est lex credendi ).

menjadi pola untuk kehidupan sehari-hari. https://alkitab.sabda.org/dictionary.php?word=ORTOPRAKSIS diakses 20 Mei 2020.

112 R. Paul Stevens, "Living Theologically,"5.

${ }^{113}$ Dua kategori lain menurut Schleiermacher adalah Teologi Historika the trunk of theological studies ibarat bagian batang tubuh dari pohon (di dalamnya studi biblika, sejarah gereja, dogmatika atau teologi sistematika) adalah penelusuran ke dalam komunitas iman Kristen, dahulu dan sekarang. Teologi Filosofis ("Ide") dari Kekristenan yang membahas hal-hal esensi, tentang konsep dan prinsip-prinsip utama atau lebih dikenal dengan sebutan root of all theology.Jeanne Stevenson-Moessner, Prelude to Practical Theology: Variations on Theory and Practice (Nashville: Abingdon, 2008), 5-6.

${ }^{114}$ Abineno. JL. C.H., Sekitar Teologi Praktika- Cetakan 3 (Jakarta: BPK Gunung Mulia, 1984), 15.

${ }^{115}$ Beek. Aart Van, Pendampingan Pastoral (Jakarta: BPK Gunung Mulia, 2007), 35.

${ }^{116}$ Friedrich Schleiermacher, Brief Outline on The Study of Theology (Berlin: M. E Bratcher, 2007), 
Selanjutnya, memastikan pelaksanaan kepercayaan atau iman tersebut terkait dengan formulasi kepercayaan Kristen lainnya. Bersifat pastoral karena Teologi Ibadah selalu berbicara dari dan berujung pada peribadatan dalam konteks ekklesiatis (ibadah komunal dalam gereja). Kebenaran yang terkuak dalam Teologi Ibadah pada akhirnya membutuhkan validasi dalam pengalaman ibadah itu sendiri. ${ }^{117}$

Teologi Ibadah bertugas memayungi keberadaan ibadah Kristen dalam komunitas gereja. New Catholic Encyclopedia menempatkan posisi Teologi Ibadah sekalipun terkait dengan cabang-cabang teologi lainnya (Ekklesiologi, Kristologi, Soteriologi) akan berujung pada tindakan ibadah. Suatu tindakan untuk mengingat perbuatan Allah di masa lampau, pemeriksaan teks-teks Kitab Suci sebagai ekspresi dari pemahaman teologis namun berujung pada peribadatan Kristen. Dengan demikian, Teologi Ibadah memayungi pelaksanaan liturgi (peribadatan) sebagai sumber istimewa ( locus theologicus ) untuk memahami gereja, tindakan sakramentalnya, dan kredo-kredo fundamentalnya. ${ }^{118}$

Keberadaan Teologi Ibadah berujung pada peribadatan dalam konteks ekklesiastis (ibadah komunal dalam gereja). Dalam tulisannya, Susan J. White menegaskan bahwa ibadah komunal dan spiritulitas merupakan dua entitas yang saling terkait. Menurutnya, “Asupan nutrisi utama bagi kehidupan rohani orang Kristen adalah di dalam ibadah komunal di gereja."119 Pernyataan White ini memiliki dua makna. Pertama, ibadah komunal memberikan dampak terhadap kehidupan spiritualitas sang pelaku peribadatan komunal tersebut. Kedua, asupan nutrisi bagi spiritualitas orang Kristen seharusnya tersedia melalui pelaksanaan ibadah komunal di dalam gereja. Dengan demikian maka gereja sebagai pelaksana ibadah komunal perlu mendesain dan melaksanakan ibadah komunal secara tepat dan berhasil memenuhi target peribadatan yang sejati.

Dyrness menyebutkan model-model ibadah komunal sejatinya adalah modelmodel spiritualitas. Kebiasaan (habits) dalam peribadatan komunal tidaklah hanya terbatas pada tembok gereja, melainkan menembusinya sehingga terasa oleh pelaku

\footnotetext{
${ }^{117}$ Friedrich Schleiermacher.
}

118 https://www.encyclopedia.com/religion/encyclopedias-almanacs-transcripts-and maps/liturgicaltheology, diakses 20 Mei 2020.

${ }^{119}$ Susan J.White, Spirit of Worship: The Liturgical Tradition (Maryknoll: Orbis, 1999), 15. 
penyembah serta orang lain di sekitarnya. ${ }^{120}$ Artinya terdapat keterhubungan dan kesinambungan yang mau tidak mau akan terwujud yaitu bahwa setiap pelaksanaan ibadah komunal menjadi petunjuk dari spiritualitas dari mereka yang terlibat di dalamnya. Tidak hanya berhenti di situ saja, melainkan spiritualitas yang timbul dari peribadatan komunal akan terpancar dan mempengaruhi kondisi pelakunya serta orang lain secara meluas. Pandangan Dyrness ini sejalan dengan penggambaran fungsi liturgi (baca: ibadah) sebagaimana G. Reimer mengistilahkan dengan kata "cermin." Fungsi liturgi sang "cermin" dalam hal ini menjadi sarana menghidupkan dan menguatkan jemaat untuk menerima sinar-sinar Injil (termasuk dogma, praksis, dan sejarah gereja) dan kemudian memantulkan kepada jemaat di dalam gereja serta orang lain di luar gereja. ${ }^{121}$ Penuturan Riemer mengingatkan adanya tugas misiologis peribadatan komunal dalam gereja, komunitas iman menjangkau dan mengubah komunitas umum.

\section{Peran Ortopati122 Teologi Ibadah bagi Spiritualitas Generasi Milenial}

Istilah ortopati berasal dari dua kata Yunani, orthos yang berarti benar dan pathos yang secara sederhana dapat disebut dengan kata afeksi. Afeksi yang dimaksudkan merupakan kecenderungan (disposisi) dan bukan sekadar berbagai emosi dan perasaan yang tidak terkendali. Kata pathos berkaitan dengan hasrat, emosi, perasaan, simpati. Makna harafiahnya mengacu kepada hasrat yang benar (right passion). ${ }^{123}$

James K. A. Smith menilai manusia dalam natur anthropologi filosofis merupakan "makhluk berhasrat" (desiring animal) ketimbang sekadar makhluk berpikir. Keberadaan hasrat itulah membuat manusia unik. Hasrat manusia menjadi pendorong yang membentuk manusia dalam berinteraksi. Penekanannya tentang cinta sebagai pendorong utama dalam hasrat hidup manusia menjadikan manusia pribadi yang utuh. Smith menilai pentingnya hasrat mencintai dalam praktek kehidupan peribadatan (berliturgi).124

${ }^{120}$ William Dyrness, A Primer of Christian Worship: Where We've Been, Where We Can Go (Grand Rapids: Eerdmans, 2009), 50-52.

${ }^{121}$ G. Riemer, Cermin Injil (Jakarta: Yayasan Komunikasi Bina Kasih/ OMF, 2002), 21.

${ }^{122}$ Umumnya makna "ortopati” lebih kepada kata "afeksi" sehingga dalam penulisan selanjutnya akan menggunakan istilah afeksi.

${ }^{123}$ R. Paul Stevens, "Living Theologically,”6.

${ }^{124}$ James K. A. Smith, Desiring the Kingdom: Worship, Worldview, and Cultural Formation (Grand Rapids: Baker Academic, 2009), 26. 
Ortopati memiliki kaitan penting dengan spiritualitas. Jonathan Edwards adalah seorang yang berjasa menghasilkan sebuah tulisan kuno mengenai afeksi-afeksi kudus memberikan dua belas tanda paten untuk upaya membangun kehidupan spiritualitas sejati. Kala itu, Edwards sedang menghadapi polarisasi yang memisahkan hati dan akal. Pada satu sisi lebih menekankan perasaan religius (religious feeling) dengan kelompok pemikiran yang benar (right thinking). Menilai polarisasi tersebut sangat dangkal maka Edwards menuliskan religious affections untuk memberikan tempat yang benar terhadap afeksi. Bagi Edwards, bagian terbesar dari spiritualitas (agama) sejati berupa afeksi-afeksi yang kudus. ${ }^{125}$

Edwards menolak untuk meremehkan afeksi sebab di dalamnya terkandung tindakan-tindakan yang penuh kekuatan dan hidup. Tindakan itu berasal dari inklinasi dan kehendak jiwa, atau aktivitas hati yang membara. ${ }^{126}$ McGrath meminjam pemikiran kognitif (Knowing God - J. I. Packer) dan penekanan afeksi (Religious Affections Jonathan Edwards) memposisikan pentingnya aspek emosional-afektif dari pengetahuan teologis ketika berelasi dengan Allah. Dengan berani McGrath menegaskan bahwa pengetahuan tentang Tuhan bukanlah semata-mata masalah akademis melainkan realitas relasional. ${ }^{127}$ Memiliki kepercayaan (belief) memang merupakan salah satu komponen dari iman yang hidup belumlah cukup. Memiliki pengetahuan intelektual saja belumlah lengkap. Seyogianya perlu melibatkan emosi, menghargai dan hidup di dalam relasi pengenalan akan Tuhan ketimbang pengetahuan tentang Tuhan semata. ${ }^{128}$

Makna substansial “orto” dari afeksi Kristen adalah tanggapan (respon) terhadap pengajaran dan kehidupan Yesus Kristus. Respon tersebut lahir dari kesadaran manusia yang menyentuh hati (ortopati) guna mengarahkan pengetahuan seseorang (ortodoksi) sehingga bertindak (ortopraksis) sebagaimana Kristus

${ }^{125}$ Jonathan Edwards, Religious Affections, vol. 2 dalam The Works of Jonathan Edwards, ed. John E. Smith, (New Haven: Yale University Press, 1959). Intisari pembahasan Edwards telah disederhanakan dan diterjemahkan ke dalam bahasa Indonesia berjudul Jonathan Edwards, Pengalaman Rohani Sejati (Surabaya: Momentum, 2003).

${ }^{126}$ Jonathan Edwards, Religious Affections, vol. 2, 95. 23.

${ }^{127}$ A.E. McGrath, Evangelicalism \& the Future of Christianity (Downers Grove: InterVarsity,1995), 9.

${ }^{128}$ Howard W. Stone; James O.Duke, How to Think Theologically, ed.2. (Minneapolis: Fortress, 2006), 
menginginkannya. ${ }^{129}$ Adanya penyatuan unsur kepala, tindakan dan hati (ortopati) semacam ini dibutuhkan oleh generasi milenial yang kecenderungannya lebih banyak menekankan akal dan tindakan sementara melalaikan unsur hati (afeksi) karena kedekatan dengan gadget menghilangkan nilai "rasa" di dalam dirinya.

Peran ortopati Teologi Ibadah dalam hal spiritual generasi milenial adalah menempatkan unsur afeksi sebagai bagian utuh manusia dalam relasinya dengan Tuhan. Artinya, generasi milenial membutuhkan kepercayaan (belief) sebagai salah satu komponen iman yang hidup, pengetahuan intelektual namun afeksi Kristen akan menjadikannya berharga di dalam relasi pengenalan akan Tuhan ketimbang sekedar pengetahuan tentang Tuhan semata.

Peran ortopati Teologi Ibadah akan terlihat dalam peribadatan komunal yang benar. Diskursus tentang keterkaitan Religious Affections - Jonathan Edwards dengan ibadah komunal ${ }^{130}$ menyimpulkan bahwa elemen-elemen di dalam peribadatan komunal (pada ibadah Minggu) dapat membangkitkan religious affections dari umat yang menghadirinya. Dengan begitu, Teologi Ibadah perlu ikut mengevaluasi dan membangun ibadah komunal yang melibatkan religious affections yang bersifat Kristiani.

\section{Implikasi Teologi Ibadah terhadap Spiritualitas Generasi Milenial}

Dari penjelasan mengenai peran ortodoksi, ortopraksis dan ortopati Teologi Ibadah terhadap generasi milenial nampaknya mengerucut pada pelaksanaan ibadah komunal $^{131}$ dalam konteks eklesiatis. Dalam tulisannya, W. Nicholls menempatkan ibadah menjadi satu-satunya aktivitas sangat penting dan tertinggi dari jemaat/gereja

${ }^{129}$ Sang-Ehil Han, Paul Louis Metger, dan Terry C. Muck, “Christian Hospitality and Pastoral Practices

from an Evangelical Perspective," Theological Education 47/1 (2012):24.

${ }^{130}$ Diskursus ini dilakukan oleh Ted Rivera, Jonathan Edwards on Worship: Public and Private Devotion

to God (Eugene: Pickwick Publications, 2010); Kendra G. Hotz dan Matthew T. Mathews, Shaping the Christian Life: Worship and the Religious Affections (Louisville: Westminster John Knox, 2006). Dalam bahasa Indonesia artikel Lucky Samuel, "Religious Affections Jonathan Edwards dan Relevansinya bagi Ibadah Komunal,” Veritas 16, No.2 (Desember 2017:183-196).

${ }^{131}$ Umumnya Kekristenan membagi dua kategori ibadah: ibadah pribadi dan ibadah komunal (korporat). Ernst Jenni dan Claus Westermann, Theological Lexicon of the Old Testament memberikan pengertian bahasa Ibrani untuk kata ibadah "abodah" (dari akar kata ebed yang berarti seorang hamba) mengindikasikan sebuah pelayanan di tempat kudus. J. H. Moulton dan G. Milligan, Vocabulary of The Greek Testament menggunakan bahasa Yunani, latreia yang berarti pemujaan atau pelayanan kepada Allah atau dewadewa. 
Kristen serta menjadi satu-satunya aktivitas orang percaya yang akan berlangsung hingga ke Surga, sedangkan aktivitas gereja lainnya sudah berhenti. ${ }^{132}$ Nicholas T. Wright menyebutkan dua alasan pentingnya ibadah. Pertama, karena Alkitab membicarakannya sebagai sentralitas kehidupan sorgawi manusia nantinya. Selanjutnya Wrigth menyebutkan alasan pentingnya adalah karena ibadah menjadi sentral tugas gereja. ${ }^{133}$

Implikasi praktis dari sifat ortodoksi, ortopraksis dan ortopati Teologi Ibadah terhadap spiritualitas generasi milenial adalah bersama gereja menyediakan ibadah yang menekankan konten, konteks dan kontainer peribadatan yang benar. ${ }^{134}$ Adapun konten/isi dalam peribadatan secara essensial berdasar pada kebenaran Firman Allah adalah pertemuan dialogis antara Allah Tritunggal dan umat tebusan-Nya. ${ }^{135}$ Oleh karena itu, konten bersifat paten dan memiliki keutamaan dan tidak boleh berubah oleh pemaknaan lain ataupun unsur-unsur pendukung lainnya. Sementara kontainer yang dalam hal ini berkaitan dengan pelaksanaan peribadatan akan menyesuaikan dengan konteks tempat gereja berada. Tentunya dalam hal ini kontainer dan konteks haruslah saling terkait dalam skala yang proporsional.

Dengan kata lain, konten ibadah komunal berpijak pada maksud ibadah dalam Kitab Suci adalah menghadirkan komunitas iman yang menekankan "relasional" akan mendatangkan pengalaman pribadi dan keterhubungan dengan Kristus dan kasih antar sesama umat penyembah Allah. Sementara, kontainer peribadatan perlu melakukan penyesuaian karena konteks bergereja sekarang ini telah men-digital, dengan tetap menjaga sifat up side down yang merupakan tugas ekklesiologis-misionalnya di dunia melalui ibadah trinitarian. Jika demikian, Teologi Ibadah menyediakan implikasi praktis terhadap spiritualitas generasi milenial melalui konten, konteks dan kontainer

${ }^{132}$ W. Nicholls, “Jacob's Ladder:The Meaning of Worship,” Ecumenical Studies in Worship No.4 (London Lutterworth, 1958),9.

${ }^{133}$ Nicholas Thomas Wrigth, For All God's Worth (Grand Rapids, MI: MI: William B. Eerdmans Publishing Company, 1997), 7.

${ }^{134}$ Penulis meminjam ide "konten, konteks dan kointainer" dari Yuzo Adhinarta, Ketua STTRI dan dosen

Teologi Sistematika dan Pemuridan; Webinar, 28 Mei 2020 tentang Future Church: Online or Offline Church. Lihat di https://www.youtube.com/watch?v=WWw7PA3MmBw.

${ }^{135}$ Materi webinar 13 Juni 2020 - GKKK Malang dan Jimmy Setiawan, “Redicovery Thy Worship” di https://www.youtube.com/watch?v=3MNjEbHxxQk. 
peribadatan yang benar.

\section{Konten Ibadah Komunal dan Spiritualitas Generasi Milenial}

Konten ibadah hakekatnya berbicara tentang makna atau esensi ibadah dalam kebenaran firman Allah. Kebenaran firman Allah merupakan bagian penting yang tak tergantikan oleh apapun dalam membangun spiritualitas orang percaya. Sebagai contoh, ketika menasehati Timotius, seorang pelayan muda dalam 2 Timotius 3:16, rasul Paulus menjadi segala tulisan yang diilhamkan Allah yaitu firman Allah sebagai dasar untuk berpijaknya berbagai aspek spiritualitasnya: perilaku, pengajaran, kerohanian serta kemampuan berelasi dengan orang lain. Jadi, konten ibadah terkait dengan makna ibadah seperti tercantum dalam Alkitab memiliki kemanfaatan untuk membentuk spiritualitas dalam berbagai aspek.

Alkitab membicarakan ibadah yang merupakan tugas sentral gereja secara esensial sebagai perjumpaan Allah dan manusia. Artinya, ibadah mewajibkan adanya dua unsur utama yang mendasar: ibadah pertama-tama merupakan tindakan Ilahi yang membutuhkan respon manusia. Keluaran 3:12 merupakan permulaan pemanggilan Allah bagi umat Israel secara komunal/korporat untuk beribadah (abodah) di Gunung Sinai. Roma 12:1-2 mencatat inisiatif Allah mendahului respon penyembahan manusia. Ibadah kepada Allah bermula dari Allah menyatakan kemurahan-Nya, setelah itu Allah menginginkan manusia mempersembahkan tubuhnya sebagai persembahan yang hidup, kudus dan berkenan kepada Allah. ${ }^{136}$ Dengan demikian, dapat disimpulkan bahwa di dalam Alkitab, keseluruhan tema yang berkaitan dengan ibadah menunjukkan bahwa Allah harus lebih dulu berinisiatif membawa manusia kedalam hubungan dengan DIA sebelum manusia dapat meresponi kehadiran Allah yang menerimanya. ${ }^{137}$

Kitab Suci mengajarkan bahwa Allah, sang inisiator ibadah adalah Allah yang trinitarian.

Untuk dapat membangun spiritualitas generasi milenial, ibadah harus bersifat trinitarian, berdasarkan pada karya Allah Tritunggal. Mengapa demikian? Jimmy

\footnotetext{
${ }^{136}$ Ferdinand Manafe. Teologi Ibadah: Ibadah yang Berkenan (Batu: YPPII, 2014), 11.

${ }^{137}$ David Peterson, Engaging with God -terjemahan Indonesia Liturgika: Sebuah Teologi Penyembahan
}

(Malang: Gandum Mas, 2017), 13. Peterson lebih suka menggunakan istilah bahasa Inggris "worship" yang berarti "yang berharga" untuk mengesankan bahwa Allah berhak menerima penghargaan tertinggi dalam setiap penyembahan manusia. 
Setiawan merumuskan ibadah trinitarian sebagai "ibadah yang ditujukan untuk kemuliaan Bapa dan hanya dimungkinkan melalui karya Kristus yang diterapkan oleh Roh Kudus dalam diri orang percaya." 138 Artinya pusat setiap peribadatan komunal seyogianya Allah, sang Bapa layak menerima kemuliaan, bukanlah manusia. Untuk dapat memuliakan-Nya maka terlebih dahulu Allah melayakkan peribadatan manusia lewat karya penebusan Kristus yang memungkinkan manusia menanggapi panggilan untuk bersekutu dengan Allah oleh pekerjaan Roh Kudus dalam dirinya.

Implikasi praktisnya adalah ibadah trinitarian harus memiliki dua unsur penting yaitu secara horisontal berpusat pada Kristus (Christological) dan penekanan relasi horisontal yang penuh kasih diantara sesama anggota tubuh Kristus. Dikarenakan karya Kristus sebagai Imam menghantar dan menyempurnakan ibadah orang percaya di hadapan Allah maka ibadah dari orang-orang percaya kepada Kristus haruslah berpusat pada Kristus. Pekerjaan Roh Kuduslah yang memungkinkan manfaat karya Kristus terjadi dalam hidup orang percaya. Implikasi kedua dari ibadah trinitarian menekankan hubungan (relasional) yang penuh kasih di antara sesama umat Tuhan. ${ }^{139}$ Hubungan relasional yang horisontal menggandaikan terjalinnya ikatan persekutuan dalam kasih terlihat dari kebersamaan antara berbagai perbedaan sosial, gender dan generasi.

Syair Kristologi tentang ke-Tuhan-an Yesus yang rasul Paulus cantumkan dalam Filipi 2:6-11 menjadi salah satu alasan mengapa ibadah trinitarian berpusat pada Kristus. Struktur teks tersebut terbagi menjadi dua bagian: ayat 6-8 berkaitan dengan pre-eksistensi Yesus yang adalah Allah sendiri, setara dengan Bapa sebelum, selama, dan sesudah masa hidup-Nya di bumi. Selanjutnya ayat 9-11 menekankan pengosongan diri Yesus sehingga Allah meninggikan dan mengaruniakan kepada Kristus nama di atas segala nama. Gelar Kyrios atau Tuhan merupakan sebuah pengakuan yang khusus, paling istimewa. Penggunaan kata "Tuhan" dalam hal ini oleh rasul Paulus menegaskan bahwa Yesus adalah Tuhan yang mempunyai kewibawaan dan kuasa penuh sebagai penguasa. Implikasi praktisnya, semua penyembahan orang

138 Jimmy Setiawan, “Ibadah Trinitarian: Definisi, Implikasi dan Aplikasi,” Veritas 14/2 (Oktober 2013)

165-197. Ketika mengutip tulisan Paul Bradshaw, "God, Christ, and the Holy Spirit in Early Christian Praying dan John Witvliet, "The Opening of Worship: Trinity" dalam The Place of Christ in Liturgical Prayer menyimpulkan bahwa bingkai trinitarian dalam ibadah merupakan hasil refleksi dan interpretasi gereja terhadap doa yang dipanjatkan oleh umat kristiani mula-mula.

139 Ibid. 
percaya harus berpusat kepada Yesus Kristus yang adalah Tuhan dan diperlihatkan lewat gerakan tubuh (gester -"bertekuk lutut"), mengaku dengan mulut bahwa "Yesus Kristus adalah Tuhan" bagi kemuliaan Allah Bapa. ${ }^{140}$ Ringkasnya, syair Kristologi tentang ke-Tuhan-an Yesus dalam Filipi 2:6-11 mengajak para penyembah dalam ibadah trinitarian untuk berpusat pada Kristus dan mengekspresikannya dalam ekpresi atau gerakan tubuh (gestur), pengakuan dan ungkapan verbatim keuniversalan dari keTuhan-an Kristus dalam pelaksanaan penyembahan orang percaya.

Sayangnya, pengakuan Kristus sebagai Tuhan dan kesempatan mengeskpresikan diri bagi generasi milenial terhalang oleh penyediaan ibadah-ibadah yang lebih bersifat kaku dan membosankan, terutama di gereja-geraja arus utama. Pengabaian dan kekakuan pelibatan tubuh menurut Marcia Shoop merupakan kecenderungan dari gereja-gereja arus utama (mainstream). ${ }^{141}$ Kritik yang lebih tajam dan provokatif dari artikel "Teaching Calvinists to Dance," oleh James, K.A. Smith, seorang profesor filsafat dari Calvin College menunjukkan kebenaran pengabaian kelompok Kalivis dalam melibatkan gestur dalam peribadatan bersama. Karena itu Smith mengakui kesukaannya bersama sang kekasih sejak muda telah menikmati ibadah yang memang secara biblika berdasar untuk melibatkan gestur dalam ibadah komunal. Itulah sebabnya ia menyebut dirinya sebagai seorang Reformed Karismatik, seorang Pentakosta Kalvinis. ${ }^{142}$

Mengkritisi minimnya gestur tubuh dalam ibadah komunal pada gereja-gereja Protestan di Indonesia, Jimmy Setiawan dalam artikelnya menilai penyebab utamanya adalah karena keengganan dan stigma serta sikap alergi para pemimpin gereja terhadap kemajuan gaya peribadatan dewasa ini. Karena itu dengan dasar teologi tubuh, Jimmy menggagas 3 (tiga) makna gestur "Liturgikal” yang sangat perlu dilakukan dalam ibadah komunal di gereja-gereja Protestan. Ketiga makna gestur tersebut adalah pengungkapan yang merupakan pancaran isi hati manusia kepada Tuhan, pelibatan yang akan

\footnotetext{
${ }^{140}$ Veritas Lux Mea, “Syair Kristologi Tentang Ke-Allah-An Yesus Dalam Filipi 2:6-11,” Jurnal Teologi dan Pendidikan Kristen, Vol. 1, No. 2 (2019): 140-154.

${ }^{141}$ Marcia Shoop, Let the Bones Dance: Embodiment and the Body of Christ (Louisville, Wesminster John Knox, 2010), 2.

${ }^{142}$ https://www.christianitytoday.com/ct/2008/may/25.42.html Christianity Today (May 2008), 42-45. Diakses 18 Juni 2020.
} 
mengaktifkan keterlibatan dalam peribadatan dan pembelajaran untuk mencari makna dari setiap gestur yang dilakukan dan bukan hanya sekedar melakukan. ${ }^{143}$

Seharusnya bila melihat gambaran ibadah Sorgawi tertera dalam Wahyu 4:9-11 tercatat secara jelas kombinasi dari ungkapan bibir dan gestur para penyembah Sorgawi kepada Allah yang duduk di atas tahta. Gambaran kombinasi mulut dan gestur seperti mempersembahkan puji-pujian, hormat, ucapan syukur kepada Dia yang duduk di atas takhta, tersungkur, menyembah Dia yang hidup sampai selama-lamanya, lalu melemparkan mahkotanya di hadapan takhta, sambil mengakui kelayakan Allah untuk menerima puji-pujian dan hormat dan kuasa; sebab Dia dalah pencipta segala sesuatu Engkau telah menciptakan segala sesuatu; dan oleh karena kehendak-Nya semuanya ada dan diciptakan. Semua wujud ekspresif penyembahan para makluk Sorgawi (di dalamnya ada kategori makhluk dan tua-tua) ditujukan kepada Allah menampilkan kombinasi ungkapan bibir dan gestur yang tepat mengingat DIA yang memang layak menerimanya. Dengan demikian, gestur tubuh sebagai penyembahan kepada Allah disertai pengakuan akan kelayakan Allah bukanlah pilihan dan perlu keterlibatan dari semua golongan, termasuk generasi milenial.

Kyle Oliver berargumen bahwa terputusnya relasi kaum tua (baby boomers) dan generasi milenial tidak hanya bersifat struktural dimarginalkan melainkan kultural. Hanya terdapat sejumlah kecil pelayan dari generasi milenial dalam keseluruhan tatanan bergereja. Hal ini hanya mendatangkan sedikit ketertarikan generasi milenial terhadap gereja. Justru kebutuhan penting bagi generasi milenial dalam pandangan Oliver jauh lebih luas dan inklusif percakapan tentang nilai-nilai setiap generasi menjadi gereja Kristus di dunia. Formasi iman mereka bertumbuh bila mendapati diri mereka menjadi bagian secara utuh dari visi yang lebih luas dari gereja. 144

Gorman berpendapat dalam hymm tentang Yesus oleh rasul Paulus digunakan sebagai rangkaian retorika perlawanan terhadap kekuasaan Romawi serta merupakan narasi utama pemikiran Paulus mengenai karya keselamatan Allah melalui ketaatan

${ }^{143}$ Jimmy Setiawan, "Menggagas Signifikansi Gestur Tubuh dalam Ibadah Korporat Gereja-gereja Prostestan," Veritas 13/1 (April 2012), 99-120.

${ }^{144}$ Kyle Matthew Oliver dalam "Faith Formation with Young Adults," Lifelong Faith Journal Special Issue Fall 2015. Kyle Matthew Oliver adalah misionaris digital dan koordinator laboratorium pembelajaran di Pusat Pelayanan Pengajaran Seminari Teologi Virginia. Dia ditahbiskan menjadi imam Episkopal pada 2012. Dia menulis blog di Misi Digital dan Contraria Sunt Complementa dan tweet di @VTS_CMTdan@kmoliver. 
Yesus untuk berkenosis atau pengosongan diri dengan mengambil rupa seorang manusia. ${ }^{145}$ Joseph Hellerman menggambarkan ketaatan yang merendah oleh Yesus sebagai sebuah "cursus pudorum" yaitu peralihan tanpa aib dari yang luhur menuju sesuatu yang berada di bawah. Tujuannya adalah untuk melawan kecenderungan tinggi hati dan kesombongan pola kelompok elit Romawi yang cenderung berlombalomba mengejar hormat dan kekuasaan, sebagaimana juga terjadi dalam jemaat Filipi. ${ }^{146}$

Ketaatan Kristus sampai mati di kayu salib sebagaimana tertera dalam Filipi 2:68 menampilkan wujud ketaatan yang dilakukan secara sempurna, totalitas (penuh komitmen yang kuat) dan tak tergoyahkan dalam pengabdian kepada tujuan-tujuan Allah. Selain memang utama dari segalanya adalah dalam kematian-Nya, Ia menunjukkan kasih kepada Bapa dan kepada umat manusia. Pengosongan diri atau kenosis dapat dikatakan sebagai wujud kesanggrahan Allah: menghadirkan contoh yang kasat mata bagi manusia dan berani mengambil risiko "tampil berbeda" dari kebiasaan yang telah terpolarisasi oleh kultur pada masa tersebut. Justru sebaliknya, kesombongan untuk menerima kehormatan dan penghargaan "ditanggalkan" demi tujuan membuka penerimaan melalui konsep yang bernuansa dialogis sebagai wujud kepedulian-Nya terhadap manusia dan dunia yang dikuasai dosa.

Berdasar penguraian Filipi 2:6-11 pelaksanaan ibadah trinitarian yang berpusat pada Kristus akan membangun spiritualitas generasi milenial bila suasana ibadah mendukung mereka bertemu langsung dalam pengalaman persekutuan dengan Kristus dalam ibadah yang diikutinya. Dampak rohani dari peribadatan demikian akan terukur melalui tindakan berani generasi milenial meninggalkan kebobrokan kultur kekinian yang tidak berafiliasi kepada tujuantujuan Allah yang mahatinggi terhadap hidup mereka. Keboborokan kultur kekinian yang dimaksud disini telah dibahas yaitu adanya kedekatan, kelekatan dan pemujaan serta "pen-dewa-an" teknologi gawai menggantikan relasi dengan Tuhan. Semestinya peribadatan yang berpusat pada Kristus menjadi landasan

${ }^{145}$ Michael J. Gorman, Michael J. Gorman, The Inhabiting the Cruciform God: Kenosis, Justivication, and the Theosis in Paul's Narrative Soteriology (Grand Rapids, Michigan/ Cambridge, U.K.: William B. Eerdmans Publishing Company: 2009), 18.

${ }^{146}$ Joseph H. Hellerman, Reconstructing Honor in Roman Philippi: Cermen Christi as Cursus Pudorum (Cambridge: Cambridge University Press, 2005), 130. 
untuk berani tampil berbeda dari semangat kerusakan moralitas dalam kultur kekinian, termasuk keberadaan gadget yang mengikatnya. Sebagai gantinya mereka akan terdorong untuk menerima panggilan beribadah dan menerima kesediaan Allah yang telah melakukan perjumpaan yang dialogis dengan manusia dalam ibadah yang disebut Dawn sebagai "royal waste of time" suatu pemborosan waktu yang "megah." Ibadah pada satu sisi nampaknya seolah-olah suatu pemborosan waktu namun sasarannya kepada Allah yang memang patut menerima penyembahan terbaik dari manusia, sehingga sementara budaya dunia akan selalu menjadi tantangan bagi kesungguhan seorang pengikut Kristus, yaitu berkomitmen untukk menjadi murid-Nya seumur hidupnya. ${ }^{147}$ Sebagaimana Kristus mewujudkan ketaatan-Nya secara sempurna, totalitas (penuh komitmen yang kuat) dan tak tergoyahkan dalam pengabdian kepada tujuantujuan Allah maka demikianlah dalam kegiatan peribadatan trinitarian yang berpusat pada Kristus. Dalam pelaksanaan ibadah memperlihatkan kesadaran penuh dan tindakan ekspresi kasih manusia terhadap kasih yang Allah telah nyatakan. Kesadaran penuh dalam Roma 12:1-2 mengharuskan keterlibatan seluruh keberadaan hidup manusia sebagai persembahan yang hidup dan berkenan kepada Allah karena telah menerima anugerah keselamatan dalam Kristus. Ini termasuk essensial kedua dari ibadah yaitu respon umat terhadap panggilan beribadah.

Berkaitan dengan respon manusia terhadap panggilan Allah, Peterson memberikan 3 (tiga) sikap hati dalam peribadatan (pribadi maupun komunal). Ketiganya adalah sikap menghormati, melayani dan menghargai Allah. ${ }^{148}$ Florovsky menyebutkan bentuk ekspresi kasih manusia yang nyata dalam ibadah misalnya puji-pujian dan penyembahan sebagai tanda pengakuan penuh syukur atas kasih Allah yang merangkul kita dan kebaikan kasih-Nya yang menebus kita. ${ }^{149}$ Sementara Evelyn Underhill menyebut doa, dan perbuatan manusia sebagai cara untuk menjawab sapaan Firman dalam beribadah. ${ }^{150}$

${ }^{147}$ Marva Dawn, A Royal “Waste” of Time: The Splendor of Worshiping God and Being Church for the World (Grand Rapids, MI:Cambridge, U.K, 1999), 1 \& 325-333.

148 David Peterson, Liturgika: Sebuah Teologi Penyembahan (Malang: Gandum Mas, 2017), 45-66

149 John D. Witvliet, Worship Seeking Understanding: Windows into Christian Practice (Grand Rapids, MI: Baker Academic, 2003), 269.

${ }^{150}$ Evelyn Underhill, Worship (London: Nisbet \& Co.,1936), 339. 
Perrin mengemukakan empat elemen penting pembentuk spiritualitas seseorang. Bila dikaitkan dengan ibadah trinitarian yang berpusat pada Kristus maka elemen pertama adalah tanggung jawab para pemimpin gereja dan pelayanan ibadah mengupayakan agar generasi milenial dapat menemukan kapasitas pencarian makna, nilai, dan tujuan dari hidup. Kedua, adanya upaya pencarian bagaimana setiap individu tumbuh dalam intimitasi, ketergantungan, dan hubungan yang saling berbagi dengan orang lain dan dunia secara keseluruhan. Ketiga, realitas yang terbentuk ke dalam pilihan-pilihan bagaimana seseorang menjalani kehidupannya. Terakhir, dihubungkan dengan upaya meneliti bagaimana orang menghidupi kehidupannya sehubungan dengan ketiga aspek di atas. Termasuk di dalamnya pemahaman tentang kehidupan dan kematian. ${ }^{151}$ Di antara dua kutub: kehidupan dan kematian itulah spiritualitas manusia dapat dimengerti - apakah dihubungkan dengan keyakinan kepada Allah atau tidak sebagai perjuangan dengan sejumlah misteri yang menghadirkan pertanyaanpertanyaan mendalam tentang kehidupan manusia.

Sebagai hasil dari ibadah trinitarian yang berpusat pada Kristus, ibadah harus bermuara pada ekspresi religius, ekspresi kepercayaan (belief) dalam sebuah komunitas iman yang bersekutu. Ekspresi yang menunjukkan sikap hormat, melayani dan menghargai Allah tersebut akan terpancar dalam praktek (practice) hidup sehari-hari dalam peran-peran sosial terhadap sesama saudara seiman dan orang-orang lain di sekitarnya.

Tanggung jawab semacam ini membutuhkan kesediaan dari para pemimpin gereja untuk fokus pada maksud keberadaannya. Gereja tidak dapat bersikap taken for granted melainkan secara sengaja membangun religious communication (membangun proses komunikasi pada masyarakat untuk menyampaikan pesan serta nilai religius untuk membentuk spiritualitas generasi millenial. ${ }^{152}$ Untuk membangun religious communication, saran John D. Witvliet, Worship Seeking Understanding: Windows into Christian Practice secara lengkap menekankan pentingnya pemahaman yang utuh dalam mempraktekkan ibadah. Seseorang perlu melengkapi pemahamannya dengan pengetahuan biblika, teologis, historis, musik dan bidang pastoral berkenan dengan

\footnotetext{
151 Ibid, 18-19.

${ }^{152}$ Handi Hadiwitanto, https://www.academia.edu/5103729/Liturgi_Sebagai_Ekspresi_Religius (diakses 20
}

Mei 2020. 
ibadah. ${ }^{153}$ Greg Scheer, menempatkan para pemimpin ibadah dengan kombinasi keahlian musikal dan wawasan teologis menjadi pemimpin ibadah generasi kekinian yang amat dicari. ${ }^{154}$ Dengan kombinasi dan spesialisasi akan mendatangkan keuntungan dalam ibadah di gereja-gereja terutama dalam penjangkauan generasi milenial.

\section{Kontainer Teologi Ibadah Menyesuaikan Konteks Spiritualitas Generasi Millenial}

James F. White menyadari adanya kekonstanan dan keperbedaan dalam bentuk sebuah ibadah. Menurutnya hal ini disebabkan oleh unsur pengulangan yang dilakukan dalam mempraktikkan struktur-stuktur dan pelayanan-pelayanan ibadah yang sama selama 2.000 tahun. Sementara orang-orang di tempat-tempat lain juga mempraktikkan hal yang sama dengan cara-cara khas mereka sendiri.155

Pernyataan White benar adanya dan menunjukkan bahwa kontainer peribadatan perlu melakukan penyesuaian karena konteks bergereja tidak pernah statis. Sartika dan Gunawan dalam Ecclesia in Transitu: Gereja di Tengah Perubahan Zaman, mengingatkan gereja akan selalu ada dalam situasi transit (ecclesia in transitu) atau biasa dikenal juga dengan ungkapan "gereja yang ada dalam perjalanan" (church in via). Dalam perjalanan tersebut, gereja perlu merespons budaya di tempat dan di masa ia hidup. Karena itu Sartika menandaskan bahwa tidak ada eklesiologi yang baku atau absolut yang dapat menjawab kebutuhan segala zaman. Bagi Sartika, tugas eklesiologi yang utama adalah untuk "menolong gereja merespons konteksnya sebaik mungkin dengan merefleksikan secara teologis dan kritis identitas konkretnya"156 Zalucha menyarankan dua penyesuaian penting gereja menghadapi perubahan zaman. Pertama penyesuaian strategis yaitu mengubah bagian-bagian yang dipandang perlu dalam hal ajaran, tata cara, organisasi dan strategi pemberitaan Injil; kedua, penyesuaian yang bersifat konsolidatif, yaitu merapatkan barisan dan memperkokoh ajaran gereja (yakni Injil) di tengah situasi dan alam pikiran manusia yang secara tegas menarik batas antara hal-hal dunia (yang nyata, yang dimengerti dan real) dengan hal-hal rohani (yang dianggap

\footnotetext{
${ }^{153}$ Lihat penjelasan dari John D. Witvliet, Worship Seeking Understanding: Windows into Christian Practice (Grand Rapids, MI: Baker Academic, 2003), 3-308.

${ }^{154}$ Greg Scheerm, The Art of Worship: Panduan Musisi untuk Memimpin Ibadah Modern (Malang: Literatur SAAT, 2015), 15-113.

${ }^{155}$ James, F. White, Pengantar Ibadah Kristen (Jakarta: BPK Gunung Mulia, 1980), 20.

${ }^{156}$ Meitha Sartika Dan Hizkia A. Gunawan, Ecclesia in Transitu: Gereja di Tengah Perubahan Zaman (Jakarta:BPK Gunung Mulia, 2018), xv.
} 
abstrak dan tidak nalar). Mencapainya membutuhkan kerelaan gereja untuk merekontruksi pelayanannya atas dasar teologi yang benar-benar berdiri atas kebenaran firman. ${ }^{157}$

Ketika mengutip tulisan Paul Meyendorff and Mark Searle, Nicholas Denysenko menyebutkan kebutuhan utama proyek pembaharuan liturgi dalam menghadapi perubahan jaman di abad ke-21 adalah menetapkan batasan pencapaiannya yang dimulai dari apa yang gereja miliki setiap kali berkumpul. Di dalam upaya tersebut, gereja dalam menjalankan misteri liturgis berkewajiban untuk mefasilitasi dan melibatkan "partisipasi penuh" (full participation) umat dalam menyembah sehingga memampukan gereja menjadi tubuh Kristus yang diubahkan oleh rahmat Allah dalam peribadatan komunalnya. ${ }^{158}$

Craig Douglas Erickson menyebutkan alasan pentingnya partisipasi penuh setiap anggota tubuh Kristus adalah karena gereja secara kolektif merupakan Imamat Rajani dan sebagai perorangan merupakan Bait Roh Kudus Allah. Konsekuensinya, gereja harus mengungkapkan 3 ciri indentitas partisipatif dalam setiap peribadatan. Ketiga ciri partisipasi yang dimaksud Erickson adalah partisipasi secara sadar (knowingly partisipatory), partisipasi secara aktif (actively partisipatory) dan menghasil buah (Fruitfully partisipatory) dalam kehidupan bermasyarakat. ${ }^{159}$

Penelitian BRC juga memperlihatkan pengaruh media yang cukup besar terhadap spiritualitas generasi muda Indonesia. Sayangnya justru gereja mengacuhkan untuk melibatkan mereka dalam pelayanan yang sudah menjadi "dunia” mereka dan gereja minim pelayanan/tidaklah digital friendly guna menyediakan konten-konten yang Kristiani bagi generasi milenial. ${ }^{160}$ Jelaslah bahwa gereja sekarang berada dalam keadaan dunia yang telah men-digital. Oleh karena itu, dalam konteks generasi milenial

${ }^{157}$ Sonny E. Zaluchu, 5.

158 Nicholas Denysenko, "A Proposal for Renewing Liturgy in the Twenty-first Century," Studia Liturgica 40 (2010) 231-59. Lihat juga Paul Meyendorff, "Liturgical Life in the Parish: Present and Future Realities,' Greek Orthodox Theological Review 48 (2003) 145-47 dan Mark Searle, Called to Participate: Theological, Ritual, and Social Perspectives, ed. Barbara Searle and Anne Y. Koester (Collegeville, Minn.: Liturgical Press, 2006) 12-14.

Baca juga tulisan Hizkia Anugrah Gunawan, "Liturgika sebagai Ruang Transformasi: Sebuah Tawaran Misional untuk Pembaruan Liturgi,” Indonesian Journal of Theology 6/1 (July 2018): 44-68.

${ }^{159}$ Craig Douglas Ericson, Partisipating in Worship: History, Theory and Practice (Louisville, Kentucky:

John Knox Press, 1989), 9.

${ }^{160}$ Handi Irawan D, dalam Dinamika Spiritualitas Generasi Muda Kristen Indonesia (Jakarta: Bilangan Research Center, 2018), 79-92. 
maka gereja perlu ada kesadaran untuk membuka kesempatan terhadap perubahan dengan penggunaan teknologi dalam sebuah peribadatan ataupun pelayanan gereja secara meluas. Berhubung generasi ini melekat dengan gadget maka gereja dalam ibadahnya perlu gadget friendly seperti menyediakan proyektor (LCD) ${ }^{161}$, menyediakan sarana komunikasi dengan gawai dalam pelayanannya kepada generasi muda. Jean Nicolas Bazin dan Jerome Cottin melihat bahwa ada tiga cara terbaik untuk mendorong internet bermanfaat bagi gereja, yaitu sebagai alat informasi, sebagai alat berdialog dan bertukar komunikasi, dan sebagai alat untuk pencerahan (enlightenment) dan kehadiran (presence) gereja dalam dunia. ${ }^{162}$

Sebagai contoh baik dari penghayatannya sebagai gereja dalam keadaan in transitu, gereja (GKI Kebonjati) telah membuat sebuah terobosan baru dalam peribatan mereka. Semangat reformasi "ecclesia semper reformanda est" mendorong gereja utuk menggunakan LED (Light Emitting Diode) dalam ruang ibadah sebagai bagian dari perubahan zaman atau sebagai media masa kini yang akan dapat menolong gereja dalam memenuhi misi Allah yaitu kesaksian dan pemberitaan Injil. Bagi mereka sarana tersebut menjadi media perjumpaan Allah dan umat dalam ibadah. 163

Dalam penelitian Bilangan Research Center menemukan ketimpangan pelaksanaan (kontainer) terhadap konteks. Alasannya gereja yang seharusnya berperan sebagai penyedia kebutuhan spiritual generasi penerusnya belum maksimal sehingga sekitar $8 \%$ atau sekitar 399 responden meninggalkan gereja. Seperti telah dikatakan bahwa ketidakmaksimalan gereja menurut riset BRC terkait erat dengan penyediaan ibadah yang membosankan (13,9\%) dan gereja tidak menyediakan komunitas $(11,2 \%)$.

Dalam artikelnya berjudul The Relevance of Corporate Worship for Generation for Generation X and Milenial Generation, Marvin A. Jones dari Trevecca Nazarene University membuat sebuah penelitian terhadap 247 responden dan hasilnya menunjukkan bahwa Generasi Milenial mencari penyembahan dengan narasi. Mereka mencari cerita tempat dirinya terlibat, afeksinya nampak serta mencari gereja dan pemimpin gereja yang otentik dan transparan dan "teman" bagi mereka. Kehadiran

${ }^{161}$ Efektivitas penggunaan LCD lihat hasil penelitian Antonius Saetban, Cik Suabuana, "Efektivitas Penggunaan Media LCD dalam Liturgi Ibadah Minggu di Gereja," Jurnal Sosioreligio Vol.15/2 (September, 2017)

\footnotetext{
162 Bazin dan Cottin, 2003: 62-63.

${ }^{163}$ Lihat tulisan penatua Agus Gunawan di http://gkikebonjati.org/artikel/renungan/gki-kebonjati-intransitu (Diakses, 18 Juni 2020).
} 
teman atau "persahabatan" dan generasi milenial sangat perlu. McMillan dan Chavis mengemukakan empat karakteristik sense of commnity antara lain: pertama, perasaan akan keanggotaan (membership), yaitu perasaan akan kesamaan dan kepemilikan akan komunitas. Kedua, perasaan akan mempengaruhi (influence), yaitu perasaan akan mempengaruhi dan dipengaruhi oleh komunitas. Ketiga, Penggabungan dan pemenuhan akan kebutuhan (integration and fullfilments of needs), yaitu perasaan di dukung oleh anggota lain dan mendukung mereka. Keempat, berbagi hubungan emosional (shared emotional connection), yaitu perasaan akan suatu hubungan, berbagi cerita, dan 'semangat' akan komunitas tersebut. 164

Menjadi tugas gereja untuk mempertahanan esensi keberadaannya sebagai persekutuan orang percaya. George Florovsky menyatakan bahwa "Keberadaan Kristen adalah secara essensial bersifat persekutuan; menjadi orang Kristen berarti berada dalam komunitas, di dalam gereja."165 Hal inilah yang memprihatinkan dalam kehidupan spiritual generasi muda sekarang ini. Gereja melalui peribadatannya seyogianya menyediakan suasana ibadah yang membangun komunitas dalam penyembahannya. Dawn mengingatkan bahaya yang mengancam dari kultur dunia yang bersifat individualistik dan kompetitif serta menyukai homogeneounitas. Padahal gereja pada hakekatnya adalah tubuh Kristus dengan berbagai anggota di dalamnya Saran bagi para pemimpin kekinian untuk pelaksaan ibadah yang lebih baik datang dari seorang dengan latar belakang seni, Greg Scheer perlu menjadi pertimbangan untuk mempersiapkan pemimpin ibadah dalam gereja. Mulai dengan menata podium yaitu upaya menkaji situasi gereja, berbagi visi atas pengkajian situasi dan mulai memperhatikan detail dari setiap faktor penunjang hasil kajian tersebut. Selanjutnya membentuk tim melalui proses rekruting, wawancara dan mulai melatih tim "baru" dalam pelayanan ibadah. Mengkaji repertoar ${ }^{166}$ menjadi bagian lain yang perlu ada. Metode yang paling sistematis dan bermanfaat untuk repertoar adalah mengkategori lagu berdasarkan isi dan fungsinya dan menganalisa pola-pola yang timbul. Kemudian barulah merencanakan ibadah dengan melihat seni dari ibadah,

${ }^{164}$ Didache: Faithful Teaching 15:2 (Winter 2016)

165 George Florovsky, “Worship and Every-Day Life: An Eastern Orthodox View,” Studia Liturgica 2 (December 1963):268.

${ }^{166}$ KBBI mengartikan Répertoar sebagai persediaan nyanyian, lakon, opera yang dimiliki seseorang atau suatu kelompok seni yang siap untuk dimainkan; daftar lagu, judul sandiwara, opera, dan sebagainya yang akan disajikan oleh pemain usik, sanggar penyanyi, dan sebagainya; Dalam Kekristenan umumnya digunakan untuk menggambarkan rangkaian jalur dalam proses peribadatan komunal. 
memahami struktur ibadah lalu mengadaptasikan struktur dan gaya ibadah dalam teknik perencanaan yang baik dan benar. ${ }^{167}$

BRC dalam penelitian mereka melihat problem spiritualitas generasi milenial dan menganjurkan kepemimpinan gereja untuk melakukan 7 (tujuh) intervensi yang perlu gereja lakukan untuk membantu spiritualitas generasi milenial Indonesia. Ketujuh intervensi tersebut adalah (a) Membangun Kepemimpinan yang kuat; (b) Kepemimpinan melalui Keteladanan; (c) Pemberitaan Firman yang Berbobot dan Relevan; (d) Mempersiapkan Mentor-mentor yang Handal; (e) Mulai Memilih dan Melaksanakan Program-program yang Inovatif; (f) Terlibat dan Terinspirasi atau Tertantang untuk melakukan sesuatu dan (g) Komunikasi antar Generasi.

Mengutip pandangan Neil Postman tentang kategori kepemimpinan yang relevan bagi generasi dengan kultur kontemporer, Dawn mendorong para pemimpin kekinian sebagai orang yang memiliki enam syarat diri. Di antaranya menjadi pemimpin yang menolak untuk menerima effisiensi sebagai tujuan utama hubungan manusia; melepaskan diri dari kekuatan magis angka; paling tidak curiga terhadap gagasan kemajuan, dan yang tidak mengacaukan informasi dengan pemahaman; tidak menganggap usia adalah tidak relevan; yang menganggap serius narasi agama; yang tahu perbedaan antara yang suci dan yang profan dan yang tidak mengedipkan mata pada tradisi demi modernitas. ${ }^{168}$

Sekalipun pelaksanaan ibadah untuk menjangkau generasi milenial perlu menyesuaikan dengan konteks namun patut menjadi pertimbangan unsur keseimbangan di dalamnya. Dawn yang menjabarkan ketegangan di antara 3 dimensi keberadaan gereja sebagai umat pilihan Allah: Inside, outside, upsidedown untuk menggambarkan tanggapan gereja terhadap "budaya" jaman yang sedang berkembang. Berusaha untuk benar-benar terjebak untuk Gereja berada di dalam dunia yang terkontaminasi dengan berbagai persoalan, dari dalamnya upaya mengerti dan melayaninya. Tidak perlu juga menjadi kelompok yang seolah-olah menolak karena mengidentifikasinya sebagai godaan atau penyembahan berhala. Sarannya justru seharusnya gereja dalam kaitannya menghadapi keberadaan "budaya" adalah memperlihatkan tanda kebijaksaannya melalui peribatan yang bersifat upside-down. Mengubah cara

${ }^{167}$ Greg Scheerm, 62.

${ }^{168}$ Marva, J. Dawn, Reaching Out without Dumbing Down, 278. 
berpikir yang bersifat selfish dunia (sebuah perbedaan otentik) karena pengajaran yang kuat berdasar kepada firman Allah.

Desakan Dawn ini sejalan dengan peringatan Brad J. Kallenber dalam bukunya God and Gadget. Kallenber menilai alih-alih menjadi murid Kristus di tengah-tengah kemajuan teknologi rupanya nampaknya manusia telah tersihir oleh teknologi. Teknologi telah sedemikian "memuridkan" manusia menjadi manusia teknopoli, hidup dalam monopoli teknologi. Kallenberger tidak sekedar menawarkan pendekatan "ya" atau "tidak" pada teknologi, tetapi mencoba meneropong lebih dalam pada tiga efek monopoli teknologi terhadap manusia: reduksionisme, standarisasi, dan instrumentalisme.

Usul yang dikemukakan oleh Kallenberg dalam menghadapi cengkraman teknologi ini adalah dengan menjadi gereja, yaitu dengan merestrukturisasi kehidupan komunitas sesuai dengan Injil bukan dengan semangat deterministik teknologi. Kallenberg justru memberikan standar penting yang gereja perlu miliki dalam kaitannya dengan penggunaan teknologi kepada sasaran pemuridan. Alasannya dalam sistem yang dinamis dari teknologi tidak dapat dicapai hanya dengan akuisisi informasi, tetapi dengan cara perwujudan pengetahuan (embodied knowledge) atau keahlian yang diperoleh melalui praktek. Oleh karena itu, perjalanan kedewasaan murid Kristus dapat terjadi hanya dengan keterlibatan sang murid secara dinamis dalam komunitas Kristen. ${ }^{169}$

Reggie McNeal dalam The Present Future: Six Tough Questions for the Church mendaftarkan juga mengingatkan gereja untuk tidak kehilangan kultur misiologis ekklesiatis oleh kemajuan zaman. Pilihan terbaik adalah membenahi kembali misiologis ekklesiatis dan para gereja modernis tidak boleh mengabaikan dan menggantikan karya Roh Kudus sebagi fokus pelayanannya terhadap perkembangan misi kerajaan Allah. ${ }^{170}$

${ }^{169}$ Brad Kallenberg, God and Gadgets: Following Jesus in a Technological Age (University of Dayton eCommons: Religious Studies Faculty Publications). Brad J. Kallenberg adalah Associate Professor Theology di University of Dayton; dia adalah penulis Live to Tell: Evangelism for a Postmodern Age (2002) dan Ethics as Grammar: Changing the Postmodern Subject (2001)

${ }^{170}$ Reggie McNeal, The Present Future: Six Tough Questions for the Church (Jossey-Bass: San Francisco, 2003), 6. 


\section{Penutup}

Dunia sedang berubah ke arah kemajuan teknologi yang pesat. Diskursus tentang generasi milenial dan persoalan keagamaan menarik kita kembali untuk memperhatikan kembali keberadaan cara kita membangun teologi dalam peribadatan kita.

Menekankan imanensi dan transendensi Allah yang hadir dalam hidup manusia sangat penting. Semua pemimpin gereja perlu melakannya dengan cara-cara yang tepat. Peringatan dan rekonstruksi solusi dari Marva J. Dawn dan tokoh-tokoh liturgis lainnya turut menunjukkan pentingnya peran Teologi Ibadah untuk menunjukkan tanggung jawab misiologisnya yang bersifat upside-down melalui ibadah kekinian guna menjawab membentuk spiritualitas generasi milenial yang berdasar pada ajaran Alkitab.

Ijinkan penulis menutup artikel ini dengan mengutip Marva Dawn yang dengan tepat menyatakan bahwa, "Akibat terburuk dari mengubah ibadah menjadi sesuatu yang dikendalikan oleh selera adalah, ketika kita melakukannya, kita telah menutup mata kita terhadap sebuah kebenaran bahwa Tuhanlah yang seharusnya disembah, bukan diri kita. Mari kita lakukan bersama-sama." Soli Deo Gloria.

\section{Kepustakaan}

\section{Sumber Buku \& Jurnal}

Abineno. JL. C.H., Sekitar Teologi Praktika- Cetakan 3. Jakarta: BPK Gunung Mulia, 1984. Badan Pusat Statistik, Statistik Gender Tematik: Profil Generasi Milenial Indonesia. Jakarta:

Kementerian Pemberdayaan Perempuan dan Perlindungan Anak, 2018. Bilangan Research Center, Dinamika Spiritualitas Generasi Muda Kristen Indonesia. Jakarta:

Bilangan Research Center, 2018.

Beek. Aart Van, Pendampingan Pastoral. Jakarta: BPK Gunung Mulia, 2007.

Bolt, John, "The Problem of Polarization in the Christian Reformed Community," dalam

Orthodoxy and Orthopraxis in the Reformed Community Today, ed. John Bolt, vol.

1, Christian Reformed Perspectives [Ontario: Paideia, 1986], 21-25.

Bowe, Barbara E. Biblical Foundations of Spirituality. Maryland: Rowman \& Littlefiled Publishers Inc., 2003.

Chesterton, G.K. Orthodoxy. New York: Dodd, Mead \& Co. 1908.

Dawn, Marva J. A Royal Waste of Time: The Splendor of Worshiping God and Being Church for the World. Grand Rapids: Eerdmans, 1999.

Dawn J Marva. Reaching Out without Dumbing Down: The Theology of Worship for the 
Turn of the Century Culture. Grand Rapids, MI: William B. Eerdmans Publishing Company, 1995.

Didache: Faithful Teaching 15:2 (Winter 2016)

Dyrness, William. A Primer of Christian Worship: Where We've Been, Where We Are, Where

We Can Go. Grand Rapids: Eerdmans, 2009.

Edwards, Jonathan. Religious Affections in The Works of Jonathan Edwards, vol. 2, diedit oleh

John E. Smith. New Haven: Yale University Press, 1959.

Florovsky, George. "Worship and Every-Day Life: An Eastern Orthodox View," Studia

Liturgica 2 (December 1963):268.

Han, Sang-Ehil, Paul Louis Metger, dan Terry C. Muck. "Christian Hospitality and Pastoral

11-31.

Practices from an Evangelical Perspective." Theological Education 47/1 (2012):

Hotz, Kendra G., dan Matthew T. Mathews. Shaping the Christian Life: Worship and the Religious Affections. Louisville: Westminster John Knox, 2006.

Lee, E. Bun. "Too Much Information: Heavy Smartphone and Facebook Utilization by African American Young Adults, 'Journal of Black Studies, Vol. 46, No. 1 (January

Manafe, Ferdinand. Teologi Ibadah: Ibadah yang Berkenan. Batu: YPPII, 2014.

McGrath, Alister E. Evangelicalism \& the Future of Christianity. Downers Grove: InterVarsity,1995.

Moessner,Jeanne Stevenson. Prelude to Practical Theology: Variations on Theory and Practice. Nashville: Abingdon, 2008.

Nichols, Stephen J. Jonathan Edwards: A Guided Tour of His Life and Thought.

Phillipsburg: P\&R, 2001.

Nicholls, W. “Jacob's Ladder: The Meaning of Worship” Ecumenical Studies in Worship No.4. London Lutterworth, 1958

Nurudin, Media Sosial: Agama Baru Masyarakat Milenial. Malang: Intrans Publishing, 2018.

Peterson, David. Engaging with God -terjemahan Indonesia Liturgika: Sebuah Teologi Penyembahan. Malang: Gandum Mas, 2017.

Rivera, Ted. Jonathan Edwards on Worship: Public and Private Devotion to God. Eugene: Pickwick, 2010.

Riemer, G. Cermin Injil. Jakarta: Yayasan Komunikasi Bina Kasih/ OMF, 2002.

Samho, Bartolomeus, dkk, Agama dan Kesadaran Kontemporer. Yogyakarta: Kanisius, 2019.

Schleiermacher, Friedrich. Brief Outline on The Study of Theology. Berlin: M. E Bratcher, 2007.

Smart, Robert Davis. Jonathan Edwards's Apologetics for the Great Awakening. Grand Rapids: Reformation Heritage, 2011.

Smith K.A. James. Desiring the Kingdom: Worship, Worldview, and Cultural Formation. Grand Rapids: Baker Academic, 2009.

Stone W. Howard dan James O. Duke, How to Think Theologically, ed. ke-2. Minneapolis: Fortress, 2006.

Stevens, R. Paul. "Living Theologically: toward a Theology of Christian Practice."

Leicester:

Themelios Journal (May 1995): 20. 
Stott, John. The Living Church. Jakarta: BPK Gunung Mulia, 2007.

Taylor, Arthur. "A study of the information search behaviour of the millennial generation,"

Information Research, Vol. 17 No. 1,(March 2012).

Tulung, Jeane Marie, dkk, Generasi Milenial Diskursus Teologi, Pendidikan, Dinamika Psikologis

dan Kelekatan pada Agama diEra Banjir Informasi. Depok, Rajawali Pers, 2019.

Underhill, Evelyn. Worship. London: Nisbet \& Co.,1936), 339.

White James, F, Pengantar Ibadah Kristen. Jakarta: BPK Gunung Mulia, 1980.

White J Susan. Spirit of Worship: The Liturgical Tradition. Maryknoll: Orbis, 1999.

Witvliet, John D. Worship Seeking Understanding: Windows into Christian Practice. Grand Rapids, MI: Baker Academic, 2003.

Wrigth, Nicholas Thomas. For All God's Worth. Grand Rapids, MI: MI: William B.

Eerdmans Publishing Company, 1997.

Woodbridge N. B.,"Living Theologically-Towards A Theology of Christian Practice in Terms of

the Theological Triad of Orthodoxy, Orthopraxy and Orthopathy as Portrayed in Isaiah 6:1-8: A Narrative Approach," HTS Teologiese Studies/Theological Studies 66/2, Art. \#807 [2010]: 3).

Yoris, Sebastian. Generasi Langgas Milenial Indonesia. Jakarta: Gagas Media, 2016.

\section{Sumber Internet}

https://www.indiegogo.com/projects/virtual-revolution-the-movie. Diakses 12 Februari 2020.

IDN Research Institute, https://www.idntimes.com/diakses 10 Februari 2020.

Kemeninfo Indonesia, https://www.kominfo.go.id/content/detail/8566/mengenalgenerasi-millennial/0/sorotan media. Diakses, 10 Februari 2020.

Sonny E. Zaluchu, Perkembangan Teologi Kristen di Dekade Pertama Abad 21. https://www.researchgate.net/publication/326694067 Perkembangan Teologi Kriste n di dekade Pertama Abad 21?enrichId=rgreq-df78f4ac4b7dca38f26d66ad7451ae13XXX\&enrichSource=Yzo2\& esc=publicationCoverPdf. Diakses 10 Februari 2020

https://www.encyclopedia.com/religion/encyclopedias-almanacs-transcripts-and aps/liturgicaltheology, diakses 20 Mei 2020.

Oxford Biblica Studies, "Orthopraxis," http://www.oxfordbiblicalstudies.com/article/opr/t94/e139 (diakses pada 20 Mei 2020).

https://alkitab.sabda.org/dictionary.php?word=ORTOPRAKSIS diakses 20 Mei 2020. Handi Hadiwitanto, https://www.academia.edu/5103729/Liturgi Sebagai Ekspresi Religius (diakses 20 Mei 2020. 


\section{Tentang Penulis}

Penulis menyelesaikan studi pascasarjana (MTh) di STT Satyabhakti, Malang. Dan kini adalah pengajar tetap di STT Satyabhakti Malang. Email: ameliarumbiak@gmail.com 